\title{
A Comprehensive Review of Low Impact Development Models for Research, Conceptual, Preliminary and Detailed Design Applications
}

\author{
Sahereh Kaykhosravi ${ }^{1}$, Usman T. Khan ${ }^{1, *}$ and Amaneh Jadidi ${ }^{2}$ \\ 1 Department of Civil Engineering, Lassonde School of Engineering, York University, \\ Toronto, ON M3J 1P3, Canada; saherehk@yorku.ca \\ 2 Geomatics Engineering, Department of Earth \& Space Science \& Engineering, \\ Lassonde School of Engineering, York University, Toronto, ON M3J 1P3, Canada; mjadidi@yorku.ca \\ * Correspondence: usman.khan@lassonde.yorku.ca; Tel.: +1-41-6736-2100 (ext. 55890)
}

Received: 21 September 2018; Accepted: 26 October 2018; Published: 29 October 2018

\begin{abstract}
This review compares and evaluates eleven Low Impact Development (LID) models on the basis of: (i) general model features including the model application, the temporal resolution, the spatial data visualization, the method of placing LID within catchments; (ii) hydrological modelling aspects including: the type of inbuilt LIDs, water balance model, runoff generation and infiltration; and (iii) hydraulic modelling methods with a focus on the flow routing method. Results show that despite the recent updates of existing LID models, several important features are still missing and need improvement. These features include the ability to model: multi-layer subsurface media, tree canopy and processes associated with vegetation, different spatial scales, snowmelt and runoff calculations. This review provides in-depth insight into existing LID models from a hydrological and hydraulic point of view, which will facilitate in selecting the best-suited model. Recommendations on further studies and LID model development are also presented.
\end{abstract}

Keywords: low impact development; sustainable urban drainage systems; stormwater modelling; numerical modelling; water resources; stormwater collection networks; green infrastructure

\section{Introduction}

Low Impact Development (LID) is an urban planning technique with the primary objective of urban flood management through source control of stormwater runoff. Using LID in urban areas is becoming one of the most popular methods for sustainable stormwater management and flood mitigation [1]. LID is a smarter and more sustainable urban development and flood management technique [2-7]. LID reduces the risk of flood through several non-structural and structural measures [8]. Some of these measures include reducing imperviousness, conserving natural resources and ecosystems, as well as constructing Green Infrastructure (GI). GIs are infrastructure which are implemented for LID purposes; some well-known examples of GIs are bioretention cells, green roofs and permeable pavements [9-14].

Despite this, the progress toward more sustainable urban development is gradual [15]. In addition to other drawbacks, one of the main reasons for this trend is the lack of comprehensive LID models or tools which can: model the complex natural process occurring within LIDs; incorporate LIDs within the wider hydrology of the watershed; and simulate the feedback and relationship with existing Stormwater Collection Networks (SCNs) $[15,16]$.

Existing LID models have diverse capabilities. The various capabilities and application of existing models complicate the decision of selecting the best-suited model for a particular application. Therefore, to make the best decision, a comprehensive comparison between the abilities of available 
models is required. This comparison will allow for obtaining knowledge about model abilities, the computational approaches within each model and contrasting the characteristics of different models. Such a comparison will help experts, scientists and even novice modelers make a more robust and timely decisions on which model to select.

Among all reviews on existing stormwater models, one study by Elliot and Trowsdale focused on LID modelling [15]. They reviewed and compared ten stormwater models for modelling LIDs. Their comparison comprises of both quantity and quality modelling abilities. In their study, some aspects (such as temporal; spatial resolution; contaminant range, generation and transport modelling) are evaluated and contrasted in detail, while other aspects (such as runoff generation methods, flow routing, hydraulic modelling abilities and detailed discussion on methods of modelling Green Infrastructures (GI)) are neglected or only discussed generally.

Two other studies reviewed LID models more general: firstly, Ahiablame, Engel and Chaubey [16] reviewed three LID-capable models: L-THIA-LID (Long-Term Hydrologic Impact Assessment- Low Impact Development), SWMM (the Storm Water Management Model) and SUSTAIN (System for Urban Stormwater Treatment and Analysis IntegratioN). In their study, individual characteristics of the models were not compared; instead, a separate brief description of each model was presented. Secondly, the City of Edmonton [17] prepared a design guide using a brief screening table on seventeen hydrologic models available to simulate LID and Best Management Practices (BMPs) practices and then selected SWMM (from the full list) for their modelling objectives.

Three other reviews on LID models focused on a specific aspect such as infiltration, water quality, or economical aspects. In one of these studies T. Carson et al. [18] evaluated the accuracy of two hydrologic methods and two hydrological models to predict green roof performance. The methods were the CN method [19] and the Characteristic Runoff Equation (CRE) [20]. The models tested were Hydrological Evaluation of Landfill Performance (HELP) [21] and SWMM. T. Carson et al. [18] compared their simulation results to an observed runoff dataset. Their results showed that HELP underestimates runoff depth for most events, in contrast to the SWMM model, which tended to overestimate event runoff depth.

The ability of some LID models to simulate water quality was addressed in another two studies. Niazi et al. [22] evaluated the capability of SWMM to simulate water quality in watersheds with LIDs (their study did not discuss the model's capability to simulate water quantity). Results of their review showed that SWMM is compatible with large and medium-scale hydrological applications. In addition, their work found that SWMM needs to be enhanced for simulating contaminant transport within GIs. In addition, Obropta and Kardos [23] compared twelve urban stormwater quality models. They categorized the models into three major classes comprised of six deterministic (SWMM; Storage, Treatment, Overflow, Runoff Model, STORM; Hydrologic Simulation Program-Fortran, HSPF; Distributed Routing Rainfall Runoff Model-Quality, DR3M-QUAL; Hydroworks, Model of Urban Sewers, MOUSE), three stochastic and three hybrid models. They concluded that hybrid approaches reduced the errors and uncertainties of the stormwater quality model results.

In another research study, Jayasooriya and $\mathrm{Ng}$ [24] focused more on the financial and economic aspects of stormwater models. They initially selected twenty of the most recent tools for modelling LID and the construction cost of different GIs. Then, from these set of models, ten were selected for comparison based on the ability of simulating stormwater management and the economic aspect of LID practices. This review did not discuss the detailed hydrologic or hydrologic modelling features; it only took into account a brief comparison between few general characteristics of the models such as the data requirement and model accuracy. General stormwater model comparisons that do not address LID modelling capabilities have also been published. In one example, Shrivastava [25] presented a brief review of fourteen existing stormwater models but did not focus on LIDs.

Although the preceding reviews present helpful information on the existing LID models, their abilities and their benefits, there is still a critical need for further review of the LID models, because the increasing popularity of LID has resulted in a widespread increase in the number of 
models available and, consequently, a broad increase in the need for models (to conduct design and performance analysis). In addition, the last elaborative review on LID models, [15], was 12 years ago and no longer adequately addresses the community's needs.

Moreover, other previous reviews lack these critical aspects: detailed hydrological and hydraulic analysis of different types of GI; their design criteria and properties; integration of stormwater collection networks with the GI within a larger watershed; spatial and temporal scale analysis; an analysis of the application of each model; and recent updates to existing stormwater models. Therefore, a review is needed to address these needs comprehensively to assist researchers and practitioners in selecting the most suitable model according to their needs. In addition, such a review will help drive innovation in features that are necessary but currently missing in available LID modelling tools.

To address these needs, in this study, eleven available models with the ability to model the hydrologic and hydraulic aspects of LIDs were selected, reviewed, compared and contrasted. These models allow for the simulation of LIDs either explicitly or implicitly. Water quality aspects were ignored for the purpose of this study; only hydrological and hydraulic systems were compared.

Thus, the overall objective of this review is twofold. First, from a user point of view, this review will help users to select the best available LID models based on their specific needs. To do this, we have considered new or recently updated LID models that have not been evaluated in the literature; we have identified the diverse capacities and capabilities of available models, considered a range of applications (i.e., research, conceptual, preliminary, or detailed design applications), and lastly, provided the most comprehensive overview of the hydrological and hydraulic aspects of LID models with sixteen different criteria (listed in Section 3). Second, from a model developer or research point of view, this review identifies the necessary but currently missing features in the current models, provides potential solutions to the limitations of the reviewed models and highlights the innovations needed to have fully functional LID models for applications related to research, as well as conceptual, preliminary and detailed design, in an effort to create comprehensive LID models to enable their widespread implementation.

To compare and contrast the models, first a set of criteria was selected. These criteria indicate the model's abilities and limitations in different fields (e.g., hydrological processes). These criteria are in three main categories. The first category is the general features of the model, including: the application of models, which shows the model's abilities in modelling watersheds at different scales; the temporal resolution (minimum and maximum allowed time steps); and the spatial data format (data visualization capability and approach of placing GI in the watershed). The second category of criteria includes the different components of the hydrological processes-this criterion is the most significant criterion in the present study because it includes the important factors that govern LID performance, which have not been widely reviewed and compared in the literature. These hydrological processes include the model's abilities with respect to the explicit and implicit modelling of different types of GI: water or mass balance; runoff generation methods; and infiltration calculation methods. Finally, the third and last category of criteria considered is the hydraulics of the systems, with a focus on flow routing methods. All three criteria are evaluated, compared, contrasted and discussed for each of the eleven selected models.

This paper is organized as follows: Section 2 presents the background regarding the selected models, Section 3 includes the evaluation and comparison of the models and Section 4 presents an analyses and discussion of the comparison results. Finally, Section 5 presents a summary and conclusion of this review.

\section{Background}

This review on GI and LID stormwater models was conducted using the following steps. First, several available stormwater models were identified (a complete list is provided in Appendix A). Of these models, eleven models were distinguished based on three main criteria: (1) models that allow for LID modelling, either explicitly or implicitly; (2) models that are in general extensively used 
for stormwater research studies; (3) models that were recently developed and require further study and analysis.

These eleven models are summarized in Table 1 . The following subsections outline the background of the selected models including: (1) the main objective of the models and the extent of use in previous research; (2) general information about the hydrological and hydraulic components; (3) notable or distinguishing features, if they exist. 
Table 1. Brief introduction to the selected models.

\begin{tabular}{|c|c|c|c|c|c|c|c|c|}
\hline ID & Model Name & Developer & Primary Objective of the Model & $\begin{array}{l}\text { Release } \\
\text { Date }\end{array}$ & $\begin{array}{l}\text { Latest } \\
\text { Version }\end{array}$ & $\begin{array}{l}\text { Open } \\
\text { Access? }\end{array}$ & $\begin{array}{l}\text { Open } \\
\text { Source? }\end{array}$ & 1,2 or $3 \mathrm{D} ?$ * \\
\hline 1 & $\begin{array}{l}\text { Green Infrastructure Flexible Model } \\
\text { (GIF-Mod) }\end{array}$ & Massoudieh et al. [26] & $\begin{array}{l}\text { Modelling hydrological and water quality } \\
\text { processes within GI practices }\end{array}$ & 2016 & $\begin{array}{c}0.1 .20 \\
\text { May } 2017\end{array}$ & $\begin{array}{l}\text { Yes } \\
{[27]}\end{array}$ & Yes & 2D-Vertical \\
\hline 2 & $\begin{array}{c}\text { Green Values } \\
\text { National Stormwater Management Calculator }\end{array}$ & U.S. EPA & $\begin{array}{l}\text { Comparing the performance, costs and } \\
\text { benefits of GI [28] }\end{array}$ & 2009 & 2017 & Yes & No & $\begin{array}{c}\text { Runoff } \\
\text { volume-based }\end{array}$ \\
\hline 3 & RECARGA & University of Wisconsin [29] & $\begin{array}{c}\text { Evaluating the performance of } \\
\text { bioretention facilities, rain gardens and } \\
\text { infiltration basins [29] }\end{array}$ & 2004 & $\begin{array}{c}2.3 \\
2004\end{array}$ & Yes & No & $\begin{array}{c}\text { Runoff } \\
\text { volume Base }\end{array}$ \\
\hline 4 & Water Balance Model (WBM) & $\begin{array}{l}\text { The British Columbia } \\
\text { Inter-Governmental } \\
\text { Partnership (BCIGP) }\end{array}$ & $\begin{array}{l}\text { Decision support and scenario modelling } \\
\text { through implementation of GIs [30] }\end{array}$ & $2003[31]$ & On-line tool & Yes & No & $\begin{array}{c}\text { Runoff } \\
\text { volume-based }\end{array}$ \\
\hline 5 & $\begin{array}{l}\text { Long-Term Hydrologic Impact } \\
\text { Assessment Model } \\
\text { (L-THIA-LID) }\end{array}$ & $\begin{array}{l}\text { Bernie Engel and Jon Harbor } \\
\text { (Purdue University) }\end{array}$ & $\begin{array}{l}\text { A spreadsheet that simulates runoff and } \\
\text { NPS pollution associated with LID } \\
\text { practices [32] for areas in the U.S. }\end{array}$ & 2000 & 2015 & Yes & No & $\begin{array}{c}\text { Runoff } \\
\text { volume-based }\end{array}$ \\
\hline 6 & $\begin{array}{l}\text { Hydrologic Engineering Centre- Hydrologic } \\
\text { Modelling System (HEC-HMS) }\end{array}$ & $\begin{array}{l}\text { U.S. Army Corps } \\
\text { of Engineers }\end{array}$ & $\begin{array}{l}\text { Simulating the hydrologic processes of } \\
\text { dendritic watershed systems [33] }\end{array}$ & $\begin{array}{c}1998 \\
\text { (as Hec-1) }\end{array}$ & $\begin{array}{c}4.2 .1 \\
\text { March } 2017\end{array}$ & Yes & No & $1 \mathrm{D}$ \\
\hline 7 & $\begin{array}{l}\text { Win-Source Loading and Management Model } \\
\text { (Win-SLAMM) }\end{array}$ & $\begin{array}{l}\text { Bob Pitt, University of } \\
\text { Alabama [34] }\end{array}$ & $\begin{array}{l}\text { Evaluating runoff volume and } \\
\text { pollution loading }\end{array}$ & 1998 & $\begin{array}{c}10.3 .3 \\
\text { May } 2017\end{array}$ & $\begin{array}{l}\text { No } \\
{[35]}\end{array}$ & No & $1 \mathrm{D}$ \\
\hline 8 & HYDRUS & PC-Progress & $\begin{array}{l}\text { Analysing water flow, heat and solute } \\
\text { transport in porous media [36] }\end{array}$ & 1995 & $\begin{array}{c}2.05 \\
\text { May } 2016\end{array}$ & Yes & Yes & 1,2 and $3 \mathrm{D}$ \\
\hline 9 & Soil and Water Assessment Tool (SWAT) & $\begin{array}{l}\text { Jeff Arnold (the USDA } \\
\text { Agricultural Research Service } \\
\text { (ARS)) and R. Srinivasan } \\
\text { (Texas A\&M University) }\end{array}$ & $\begin{array}{l}\text { Quantifying and predicting the impact of } \\
\text { land management practices in large } \\
\text { complex watersheds [37] }\end{array}$ & 1990 & $\begin{array}{l}\text { SWAT2012 } \\
\text { rev. } 664 \\
\text { October } 2016\end{array}$ & $\begin{array}{l}\text { Yes } \\
{[38]}\end{array}$ & Yes & $1 \mathrm{D}$ \\
\hline 10 & $\begin{array}{l}\text { MIKE Urban/Model for Urban Sewers } \\
\text { (MOUSE) }\end{array}$ & DHI Inc. & $\begin{array}{l}\text { Modelling system for analysis of urban } \\
\text { drainage and sewer systems [39] }\end{array}$ & 1983 & $2016[40]$ & No & No & $1 \mathrm{D}$ \\
\hline 11 & Storm Water Management Model (PCSWMM) & $\begin{array}{l}\text { Computational Hydraulics } \\
\text { International (CHI) }\end{array}$ & $\begin{array}{c}\text { Dynamic hydrological and hydraulic } \\
\text { modelling of watershed and runoff [41] } \\
\text { collection networks considering LIDs as a } \\
\text { component [42] }\end{array}$ & 1971 & $\begin{array}{c}\text { 7.1.2480 } \\
\text { October } 2017\end{array}$ & No & No & $1,2 \mathrm{D}$ in plane \\
\hline
\end{tabular}

${ }^{*}$ Number of physical dimensions that can be modelled. 


\subsection{Green Infrastructure Flexible Model (GIF-Mod)}

The objective of GIF-Mod is to simulate water quality, hydrological and hydraulic processes within GIs (further information is presented in Table 1). GIF-Mod is a newly developed model and has not been used widely in other studies.

Hydrological and hydraulic elements in GIF-Mod are represented in form of "blocks" and "connectors". Six types of blocks are used for representing different media including soil, surface pond, stream segment, groundwater, catchment and storage and connectors are conduit elements (open channel or pressured pipe) [26,43].

In terms of hydrological and hydraulic modelling, the governing equations used within the blocks and connectors are simplified analytical equations (e.g., the van Genuchten-Mualem equation for flow rate in the soil block or the Manning equation in the connectors). Thus, GIF-Mod does not use numerical methods (e.g., finite difference, etc.) within any of its blocks.

GIF-Mod includes an inverse modelling feature, which is used for either designing or model calibration purposes.

\subsection{Green Values (National Stormwater Management Calculator)}

The National Green Values Calculator model is an online tool to estimate GI performance, benefits, costs and comparing it with SCNs (noted as "conventional" in the model). Table 1 provides a brief introduction to the models. This tool was used in a few research studies (e.g., [44,45]) for mostly cost and benefit calculation of GIs. The Graphical User Interface (GUI) of the Green Values is in form format, in which the user enters the input data.

Since the program objective is estimation rather than detailed design, detailed input data is not required. Therefore, providing general information such as the catchment area, land cover before and after LID treatment, runoff reduction goal, and types, characteristics and numbers of GI is adequate, and providing any detailed spatial data such as topographical data is not necessary. Green Values simplifies the hydrological processes by using Curve Number $(\mathrm{CN})$ method. It assigns a $\mathrm{CN}$ to each type of land cover and GI, then calculates the runoff from a predefined regional rainfall data [46].

\subsection{Hydrologic Engineering Centre-Hydrologic Modelling System (HEC-HMS)}

This model was developed for modelling the hydrological response of dendritic watershed systems [47] and has been extensively used in numerous research studies by hydrologists and engineers. However, HEC-HMS has not been used widely for LID modelling purposes; studies such as $[48,49]$ used HEC-HMS for LID modelling objectives.

In HEC-HMS, hydrologic and hydraulic elements are classified into three categories: basin, meteorological, and time series components. In addition, some hydraulic elements such as conduits or reservoirs are available to connect the sub-basins. The governing equations used in the model are diverse, e.g., there are several options to model infiltration (Horton, Green-Ampt, among others), whereas limited options to model conduit flow (the kinematic wave equation); details are discussed in the following sections.

Recently, some additional features were incorporated into HEC-HMS such as uncertainty analysis, sediment transport, erosion modelling and water quality associated with nutrients [50]. More information about this model is presented in Table 1.

\subsection{HYDRUS $1 D$}

HYDRUS 1D is a numerical model for water, vapor, heat and solute transport within soil media (more information is presented in Table 1). HYDRUS 1, 2 and 3-D has been extensively used in previous research, with various objectives; however, research related to LID is limited (e.g., [51,52]).

Hydrological elements of HYDRUS 1D consist of soil properties and meteorological time series such as precipitation. In terms of hydraulic modelling, except for outflow from underdrain pipes, 
it does not allow for modelling conduits or pipes. HYDRUS 1D cannot import any type of data as input, and the user needs to enter the data manually. The governing equations in HYDRUS 1D are Richard's equation for modelling flow within the vadose zone and the saturated soil. In addition, Fickian-based advection-dispersion equations are used for modelling heat and solute transport $[30,53]$.

One of the notable features in HYDRUS 1D is that it is capable of inverse modelling, which allows for model calibration or design objectives.

\subsection{Long-Term Hydrologic Impact Assessment Model (L-THIA-LID)}

The L-THIA LID model is a conceptual model developed for a custom region (Table 1 presents more information). It is a popular model and has been applied in numerous research studies in the literature (e.g., [54]).

The GUI of the model is in the format of a form, in which the user needs to select or enter data. L-THIA-LID carries out a volume-based computation of runoff reduction for LIDs. These computations are based on determining the combination of land use, related LID practices and CN. Then runoff volume reduction calculations are done using the composite Curve Number $(\mathrm{CN})$ method [19]. L-THIA-LID computes current, post-development without LID, and post-development with LID runoff volume for comparison [55]. However, hydraulic elements such as conduits are not included in L-THIA-LID.

\subsection{MIKE Urban}

MIKE Urban is a parent computer program, which is powered by SWMM, MOUSE and a water distribution model [56]. It is also extendable to MIKE Urban FLOOD 2-D modelling [57]. Table 1 presents more information about MIKE Urban.

In MIKE Urban, the SWMM module is the component in which the LID is modelled. SWMM model was first developed by U.S. Environmental Protection Agency (EPA) in 1971 [36]. SWMM allows for hydrology (runoff generation and flow routing) and hydraulic modelling (SCN modelling) of catchments [36]. It also includes LID modelling tools. Due to the diversity of hydrologic and hydraulic computation methods and free access to the model, SWMM is one of the most popular models among researchers. However, commercial versions, such as MIKE Urban, have extra features to SWMM, which facilitate the modelling process (e.g., improved GUI and GIS capacity).

One of the extra features of MIKE Urban is allowing for 2-D presentation of flooded plane by linking SWMM and MIKE Urban FLOOD 2-D model [57].

\subsection{RECARGA}

RECARGA is a tool for designing and analysing three types of GIs, including bioretention cells, rain gardens and infiltration basins [34]. Table 1 provides a more details of the model. RECARGA has been used in many LID research studies (such as [58] and [59]).

RECARGA performs hydrological modelling, but does not perform hydraulic modelling of SCNs. It is a MATLAB-based computer program with a graphical user interface [24]. For calculation of run-on from a previous area, the SCS CN method is used and for infiltration calculations the Green-Ampt [60] and van Genuchten [61] methods are used. Input data are entered by a user or imported as a text file; other file formats cannot be used.

\subsection{Storm Water Management Model (PCSWMM)}

PCSWMM is another commercial version of SWMM and a third-party interface for SWMM. A LID modelling tool was added to SWMM, and it has been used in PCSWMM, as well, since 2010 (Table 1 presents more information about PCSWMM).

The hydrological and hydraulic modelling of LIDs in SWMM and PCSWMM are some of the most popular among scientists, and have frequently been addressed in many research studies (e.g., [62,63]). 
However, due to some simplifications made in the hydrological and hydraulic processes within LIDs, the capability of this model in simulating LIDs needs further evaluation and discussion.

PCSWMM added several features to SWMM to facilitate the modelling process. One of these features is a data visualization tool to help create maps. PCSWMM presents extra features such as an integrated 1D-2D modelling environment, sensitivity analysis and calibration error analysis [35].

\subsection{Soil and Water Assessment Tool (SWAT)}

SWAT is mainly a climatic and hydrological process model with a major focus on sediment and contaminant transport. This model analyses the effect of BMPs on vast and complex dendritic watersheds [37]. SWAT is one of the most popular models for hydraulic modelling of surface runoff in large-scale basins. Because of its capability of modelling BMPs and LIDs, SWAT was widely addressed in the literature [64].

In terms of hydrological modelling, SWAT presents one of the most complex water balance models. It considers parameters such as soil water content, precipitation, runoff, evapotranspiration, tree canopy, subsurface and percolation $[37,65]$. The climatic processes modelled in SWAT are comprised of precipitation, air temperature, soil temperature and solar radiation. Hydraulic modelling of streams in SWAT are not dynamic.

However, it has extra features which determine the sediment yields, channel erodibility and flow routing [37]. These features help modellers to simulate the effect of LIDs or BMPs on the quality of surface runoff.

\subsection{Water Balance Model (WBM)}

WBM is web-based conceptual model launched by the Union of British Columbia Municipalities (UBCM) (Table 1 provides further information about the model) [66]. WBM is defined as a decision-making model for identifying the best model among different scenarios of LIDs. It has been addressed in some research studies, but more evaluations of the model are needed.

The GUI of WBM is in a form format, in which the users need to enter the properties of the hydrological elements such as watershed or LIDs manually. The hydrological computation is based on assigned properties of the hydrological elements (e.g., ratio infiltration rate of the LIDs) and is a lump generation of LID runoff reduction. WBM does not include hydraulic elements such as conduits or perform any hydraulic calculation.

\subsection{Win-Source Loading and Management Model (Win-SLAMM)}

Win-SLAMM was developed for interpreting the relationship between runoff quality and the sources of pollutants in urban areas $[67,68]$. It is carried out with a focus on small storms, which are more important for source control of runoff quality [69]. Table 1 presents a brief introduction to the model.

The hydrological modelling in Win-SLAMM is based on actual field observations [70], with a basic dependence on theoretical processes [71]. Hydraulic modelling in Win-SLAMM is simplified and it does not perform flow routing unless a flow control device (e.g., a GI) is added.

Win-SLAMM includes two extra features: a cost calculation value and an uncertainty analysis tool [24].

\section{Comparison of Models}

Sixteen criteria were considered to compare the selected models. The selected hydrologic and hydraulic criteria are essential features required for simulating different types of LID in a model and provides a broad insight for the modelers to decide on which model is best suited for their needs. In addition to these, other general modelling requirements are contrasted. Considered criteria were defined into three main categories: (1) general features, including the model application, the temporal data resolution, the spatial data visualization approach, the method of placing GI in the hydrologic 
model; (2) hydrological modelling aspects, including the type of inbuilt GI available within the model, run-on, snowmelt, evaporation and water uptake by plants, runoff generation used and infiltration process; and (3) hydraulic modelling methods, with a focus on the flow routing method. Table 2 presents the comparison criteria considered in this study. The following sections will present the comparison process and the results.

Table 2. Criteria considered for comparing the selected models.

\begin{tabular}{|c|c|c|}
\hline Level 1 Criteria & Level 2 Criteria & Level 3 Criteria \\
\hline General features & $\begin{array}{r}\mathrm{T} \\
\text { The sp } \\
\text { The method }\end{array}$ & $\begin{array}{l}\text { Model application } \\
\text { temporal data resolution } \\
\text { ial data visualization approach } \\
\text { f placing GI in the hydrologic model }\end{array}$ \\
\hline \multirow{2}{*}{$\begin{array}{l}\text { Hydrological } \\
\text { modelling aspects }\end{array}$} & $\begin{array}{l}\text { The type of inbuilt GI } \\
\text { available within the model }\end{array}$ & $\begin{array}{c}\text { Availability of predefined GI elements } \\
\text { Modelling water ponding at the surface } \\
\text { Modelling underdrain pipes } \\
\text { Modelling cisterns and rain barrels } \\
\text { Modelling multiple layers of soil or other material } \\
\text { Modelling sloped catchments }\end{array}$ \\
\hline & Water balance & $\begin{array}{c}\text { Run-on } \\
\text { Snowmelt } \\
\text { Evaporation } \\
\text { Water uptake by plants }\end{array}$ \\
\hline
\end{tabular}

Runoff generation and infiltration process

Hydraulic modelling methods

Flow routing method

\subsection{Model Application}

The main purpose of modelling a watershed is to predict the behaviour of the watershed under different conditions or future scenarios, e.g., to manage the water resources or predict flood conditions. To do this, a watershed modelling process is needed. For most stormwater projects, this process includes research, conceptual, preliminary and detailed design phases. Each of these phases has different applications, into which the eleven selected models were categorized and described below.

One of the main applications of LID models in the research phase is the design and optimization of a single unit of GI (e.g., a single bioretention cell or green roof). In this review, this is considered to be a GI design and optimization application. The next phase is conceptual design, where the effect of the LID on a catchment is estimated. Therefore, conceptual design is considered to be the second class of application in this review. The third and fourth phases, preliminary and detailed design, involve more details than conceptual design phase. The application of preliminary and detailed design phases is designing hydraulic and hydrological elements in more details. Thus, models well suited for this application are considered in this class.

For the research phase, i.e., the GI design and optimization category, tools with the ability to model mechanisms occurring within any type of GI are required. Thus, a suitable model for this is required to model: multiple subsurface media layers, including different materials for each layer (such as soil or any other porous materials); ponding on the surface; drainage of the lowest layer; water movement in the vadose and saturated zones; a complete water balance model to consider interception, water uptake by roots, evaporation, transpiration and snowmelt. Among the selected models, as shown in Table 3, GIF-Mod [26], HYDRUS 1D [30], and RECARGA [34,68] are suitable tools for this purpose. However, RECARGA can only design bioretention cells with some limitations, which is discussed in the following sections. 
Three out of eleven selected models (GREEN VALUES [46], L-THIA-LID [31] and WBM [39]) are suitable for conceptual design purposes. These models are mostly in the form of spreadsheets or user-entry forms. They compute the effect of LIDs through simplified runoff volume calculations.

These three models (L-THIA-LID and GREEN VALUES, WBM) have been designed for specific regions and rainfall data and thus, are location dependent and therefore not applicable in other regions. It is notable that among these three models, GREEN VALUES can provide an estimate of costs and benefits associated with selected LIDs [46].

The remaining five models (HEC-HMS [47], MIKE Urban [57], PCSWMM [35,36], SWAT [37,65] and WIN-SLAMM [41]) are better suited for more advanced modelling phases, preliminary and detailed design. These models provide most of the detailed stormwater modelling calculations such as peak flow, runoff amount, flow routing method and flow depth and volume within conduits. However, Win-SLAMM is not suitable for preliminary design, because of the amount of detailed information required in its modelling stages.

Table 3. Comparing the selected model applications.

\begin{tabular}{|c|c|c|c|c|c|c|c|c|c|}
\hline Applications & $\sum_{0}^{0}$ & 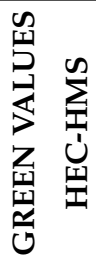 & 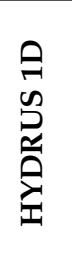 & 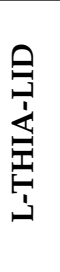 & 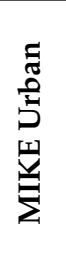 & $\sum_{\substack{\infty \\
\sum}}^{\sum}$ & 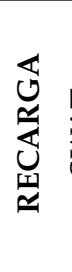 & 量 & $\sum_{3}^{\infty}$ \\
\hline GI design and optimization (research) & $\checkmark$ & & $\checkmark$ & & & & $\checkmark$ & & \\
\hline Conceptual design & & $\checkmark$ & & $\checkmark$ & $\checkmark$ & $\checkmark$ & & $\checkmark$ & $\checkmark$ \\
\hline Preliminary and detailed design/analysis & & $\checkmark$ & & & $\checkmark$ & $\checkmark$ & & $\checkmark$ & \\
\hline
\end{tabular}

\subsection{Types of Pre-Defined GI Available in the Model}

A main objective of this review is to compare the ability of the selected tools to simulate LIDs incorporated in a watershed. This comparison will assist the reader in determining which models can be used to simulate specific GI, either explicitly or implicitly. Two main approaches are used in all of the reviewed models: they either consider GI to be a predefined element in the model, or do not include GI as a predefined element, but instead allow for implicit modelling of GI. Thus, for the latter approach, the tools' abilities in implicit modelling of GI are evaluated. For implicit modelling of GI, the model needs to have potential capabilities such as modelling water ponding at the surface, underdrain pipes [72], multiple layers of media (e.g., soil or other porous material), and modelling sloped catchments (e.g., considers swales as a sloped catchment or a grassed channel). For instance, to model a bioretention cell, all three of these capabilities are required. Therefore, these required capabilities are evaluated and contrasted for implicit GI models.

For the comparison, eight types of GI were identified: bioretention cells, rain gardens, porous pavements, swales, green roofs, cisterns/rain barrels, infiltration trenches/box planters and tree canopies. These types of GI are frequently cited in the literature and are the main type of GIs; other types of GI can be considered as a sub-category. In Table 4, the potential of each model for simulating these eight different types of GI as an explicit or implicit element is presented. 
Table 4. Capability of the selected models in modelling different types of GI.

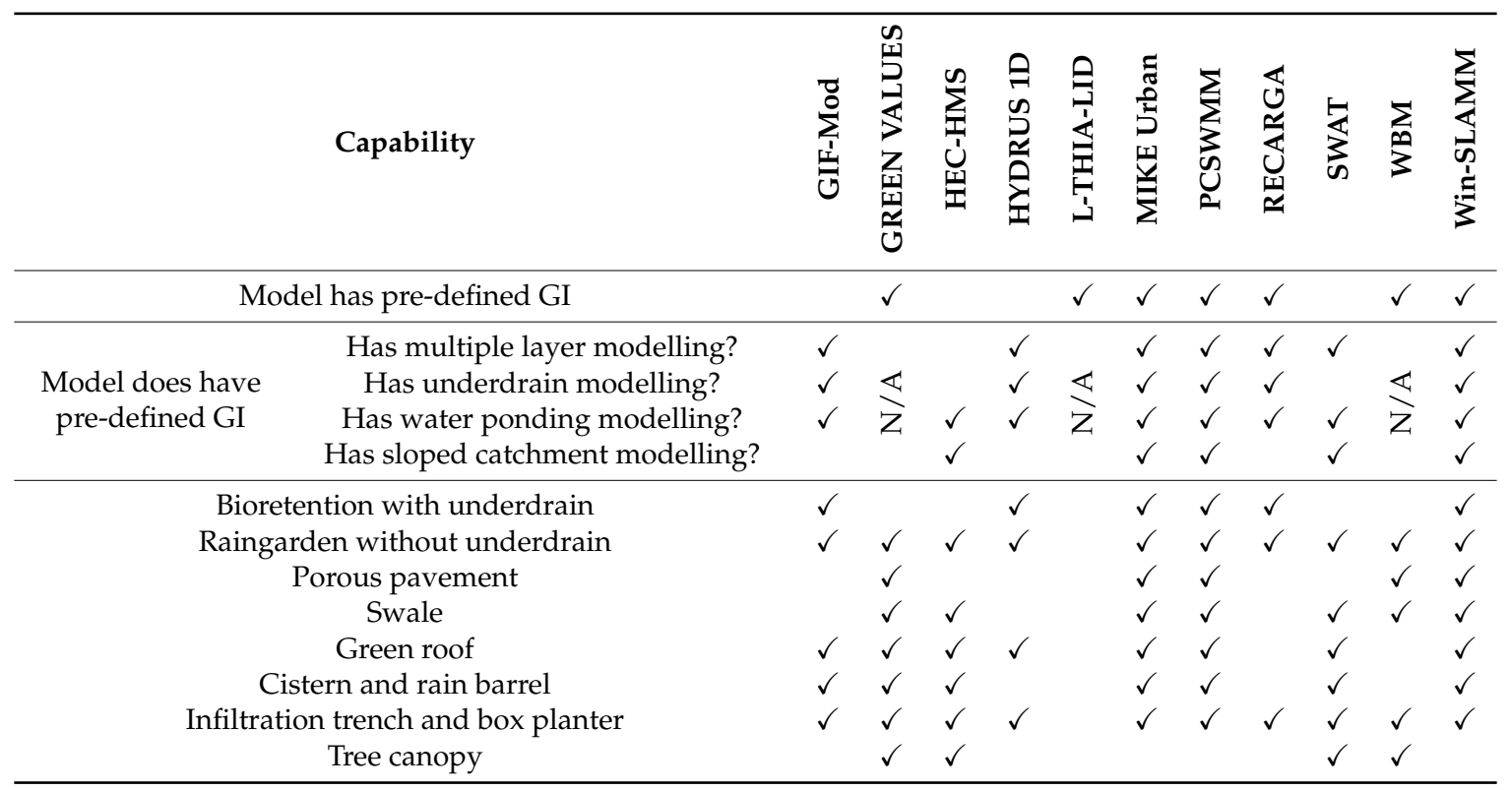

\subsubsection{Availability of Predefined GI Elements}

Seven of the eleven models (GREEN VALUES, L-THIA-LID, MIKE Urban, PCSWMM, RECARGA, WBM and WIN-SLAMM) have inbuilt capabilities to model GI explicitly. Users can simply choose the type of predefined GI in the model, enter the design parameters and perform the simulations. In the other four models (GIF-Mod, HEC-HMS, HYDRUS 1D and SWAT), however, GI should be defined implicitly. To simulate GI in these models a sub-catchment is considered to be a GI and the characteristics of that sub-catchments is assigned identical to the GI properties.

\subsubsection{Modelling Water Ponding at the Surface}

Many types of GI (e.g., rain gardens) include a berm, which allows for ponding of water at the surface. The ponded water infiltrates into the GI gradually and enhances the GI efficiency (by reducing surface runoff). Therefore, modelling the water ponding at the surface is an important component of LID models.

From the selected models, GIF-Mod models water ponding on the surface as a surface pond block, which detains depression storage [43]. HYDRUS 1D has the feasibility of defining ponding on the surface by the user as an upper boundary condition. However, in HEC-HMS, surface ponding is not included in the model [50]. Ponding is modelled implicitly in HEC-HMS by assigning ponding as a loss method (Soil Moisture Accounting Loss Model). This loss method considers the soil to have two layers and allows for surface ponding implicitly. This method has a major limitation, which is that the infiltration versus time relationship is assumed to be linear, which is a simplification of the non-linear infiltration process [73]. With this method, the infiltration decreases from a maximum user-defined amount to zero-which occurs when the soil storage capacity is met (this capacity is defined by the user). This assumption (that infiltration is zero at maximum soil storage capacity) is too simplistic for LID applications and thus, not suitable for LID modelling objectives.

In SWAT, ponds, wetlands and reservoirs can be defined as water bodies; the limitation with this is that users are allowed to define up to two water bodies per each sub-catchment. However, water entering the ponds and wetlands is generated in the same sub-catchment and they cannot receive water originating in other sub-basins. In contrast, reservoirs receive water contributed to the channel network from all upstream sub-basins [65]. This special property of SWAT limits linking the GI from different sub-catchments. In addition, in SWAT, seepage from the pond to the soil is simplified. Seepage volume is considered to be a function of saturated hydraulic conductivity multiplied by 
the pond area [37] —-this assumes that the antecedent soil moisture content is saturated, which is not always the case for LIDs.

\subsubsection{Modelling Underdrain Pipes}

Underdrains are usually a component of bioretention cells. Thus, to model a bioretention cell implicitly, a tool with the capability of modelling underdrain conduits is required. Two of the selected models (HYDRUS 1D and GIF-Mod) allow for defining an underdrain pipe in the lower layers. In HYDRUS 1D, pipes can be allocated in three different vertical positions, distributed in the horizontal direction in any interval and sized by the user. Meanwhile, GIF-Mod allows for adding pipe to any layer of the soil and the outlet is allowed to be connected to other blocks (e.g., catchment blocks). However, modelling underdrain pipes HEC-HMS and SWAT is not possible. Thus, in these two latter models, if a GI requires an underdrain, modelling is not possible.

\subsubsection{Modelling Cisterns and Rain Barrels}

Cisterns and rain barrel are detention elements [11] which are typically much smaller compared to the main catchment. Thus, any hydraulic elements in the model which are similar to a reservoir and accept inflow from the sub-catchments, perform flow routing and provide a flow pattern for downstream catchments can represent a cistern or rain barrel. From the selected models, GIF-Mod, HEC-HMS and SWAT allow modelling these elements, implicitly, using hydraulic elements such as reservoirs or detention water bodies. However, HYDRUS 1D does not allow this type of reservoir simulation.

\subsubsection{Modelling Multiple Layers of Soil or Other Material}

The number of soil, growing media, or subsurface layers is important in modelling some types of GI, such as bioretention cells. Three models, GIF-Mod, HYDRUS 1D and SWAT allow for modelling multiple layers. In HEC-HMS the soil layers are considered to be a single layer, but one loss methods (Soil Moisture Accounting Loss Model) within the model can divide this layer into two regions (upper zone and tension zone) [47].

The other seven selected models have inbuilt GIs, in which the number of soil layers is pre-determined and the models do not allow for increasing the number of layers. For instance, the number of soil layers allowed to be modelled in RECARGA is limited to three layers: two layers for bioretention cell and one layer for natural soil—the user cannot modify these layers.

\subsubsection{Modelling Sloped Catchments}

Swales are grassed channels, which convey and infiltrate runoff at the same time. The ground surface in swale is inclined which facilitates the water movement along the swale [11]. Five of the eleven models (HEC-HMS, MIKE-Urban, PC-SWMM, SWAT and Win-SLAMM) allow for modelling these types of swales either as sloped catchments (using hydrological flow routing) or grassed channels. In addition, the conceptual models (GREEN VALUE L-THIA-LID and WBM), as expected, only consider swales in terms of runoff volume reduction. The other three models (GIF-Mod, HYDRUS 1D and RECARGA) do not allow for sloped surface modelling of the GI, which limits modelling any GI with an inclined surface.

\subsection{Temporal Data Resolution}

A comparison of temporal resolution of the selected models is presented in Table 4, which considers five classes, ranging from seconds to annual resolution. Conceptual models (GREEN VALUES, L-THIA-LID and WBM) use the lumped amount of rainfall for a period of time (e.g., maximum annual or daily rainfall). GREEN VALUES uses the annual and storm-event lumped 
amount [46], while L-THIA-LID only uses the annual volume of rainfall [31] and WBM uses an hourly lumped amount [15].

Five models (GIF-Mod, PCSWMM, MIKE Urban, HYDRUS 1D and SWAT) accept a wide range of temporal resolution from fine to coarse time steps (Table 4). Thus, modelling rainfall data with any time interval from sub-hourly to annual resolution is feasible in these five tools. The other three models (HEC-HMS, RECARGA [34] and WIN-SLAMM) only allow for fine (i.e., per minute) temporal resolutions (Table 5). Therefore, modelling historical rainfall data (annual or monthly data series) is restricted in these models.

Table 5. Comparing the temporal resolution of the selected models.

\begin{tabular}{|c|c|c|c|c|c|c|c|c|c|c|c|c|}
\hline \multicolumn{2}{|c|}{ Resolution } & 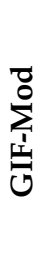 & 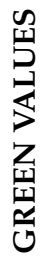 & 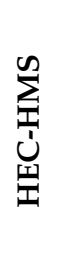 & 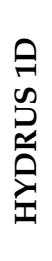 & 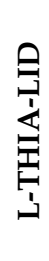 & 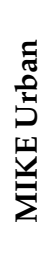 & $\sum_{\substack{\infty \\
\infty}}$ & 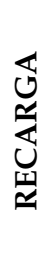 & $\sum_{\infty}^{\frac{1}{3}}$ & $\sum_{3}^{\infty}$ & $\sum_{\substack{\infty \\
\vdots}}^{\sum_{3}^{1}}$ \\
\hline \multirow{5}{*}{ Distributed } & Annual & $\checkmark$ & & & $\checkmark$ & & $\checkmark$ & $\checkmark$ & & $\checkmark$ & & \\
\hline & Monthly & $\checkmark$ & & & $\checkmark$ & & $\checkmark$ & $\checkmark$ & & $\checkmark$ & & \\
\hline & Daily & $\checkmark$ & 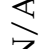 & $\checkmark$ & $\checkmark$ & $\lesssim$ & $\checkmark$ & $\checkmark$ & & $\checkmark$ & $\lesssim$ & $\checkmark$ \\
\hline & Hourly & $\checkmark$ & & $\checkmark$ & $\checkmark$ & & $\checkmark$ & $\checkmark$ & $\checkmark$ & $\checkmark$ & & $\checkmark$ \\
\hline & $\mathrm{Min} / \mathrm{Sec}$ & $\checkmark$ & & $\checkmark$ & $\checkmark$ & & $\checkmark$ & $\checkmark$ & & $\checkmark$ & & \\
\hline \multicolumn{2}{|c|}{ Lumped } & & $\checkmark$ & & & $\checkmark$ & & & & & $\checkmark$ & \\
\hline
\end{tabular}

\subsection{Spatial Data Visualization Format and Approach of Placing GI in Catchment}

Modelling large-scale watersheds usually includes dealing with complex spatial features. This demands a modelling tool in which geospatial information can be included, processed and visualized. A spatial data visualization tool integrated into the modelling environment yields numerous advantages such as better understanding the catchment via visual inspection; detecting the source of errors in the model; identifying important patterns within the results and facilitating the modification of the spatial data. Modelling in such an environment ultimately leads to the higher accuracy of the results, as well as saving time during the modelling process.

In recent versions of many stormwater models, the capability of visualizing spatial information has been added. In contrast, other models still do not allow for importing common formats of spatial data and do not offer data visualization tools. Three out of the eleven reviewed models (MIKE Urban, PCSWMM and SWAT) incorporate GIS tools within the model environment, making it possible to import and export spatial data. PCSWMM and MIKE Urban allow for adding and removing vector and raster data into the model, customizing the symbols and altering the data attributes. However, spatial data analysis, which includes features such as intersecting, merging, calculating multiple layers as it exists in GIS, is not allowed in these two models (i.e., they are dynamic maps with limitations). PCSWMM presents some extra hydrological spatial features such as automatic delineation of the watershed or finding the river sections from the Digital Elevation Model (DEM) data. MIKE URBAN uses DEM as either static background map or for manually detecting the invert of waterways. However, if the SWAT extension (ArcSWAT) is used the benefits from all GIS dynamic map visualization and analysis are included.

However, Win-SLAMM plans to introduce GIS "linkage" (Arc-SLAMM) in the future [74] and HEC-HMS needs a "Geospatial Hydrologic Modelling Extension (HEC-GeoHMS)" for this purpose. The other six tools are either conceptual models and do not need spatial data processing (GREEN VALUE, L-THIA-LID and WBM) or the data needs to be entered by the user (GIF-Mod, HYDRUS 1D and RECARGA) (Table 6). 
Table 6. Comparing spatial data visualization format and approach of placing GI in the catchment.

\begin{tabular}{|c|c|c|c|}
\hline \multicolumn{3}{|c|}{ Spatial Data Visualization } & 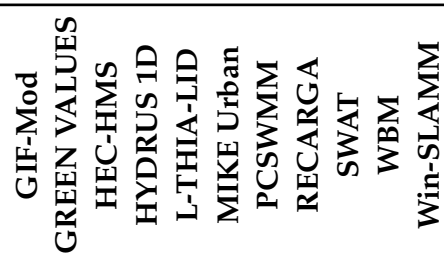 \\
\hline Data visualization format & \multicolumn{2}{|c|}{$\begin{array}{l}\text { Text, spreadsheet, or blank field } \\
\text { Map }\end{array}$} & 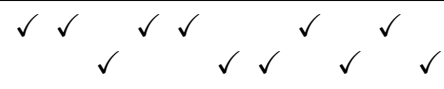 \\
\hline \multirow{2}{*}{$\begin{array}{l}\text { Defining LID practices in } \\
\text { each sub-basin }\end{array}$} & $\begin{array}{l}\text { LID practices are assigned } \\
\text { within sub-basin }\end{array}$ & $\begin{array}{c}\text { as GI } \\
\text { as a new land use }\end{array}$ & $\begin{array}{lll} & \checkmark & \checkmark \\
\checkmark & & \checkmark\end{array}$ \\
\hline & $\begin{array}{l}\text { LID practices are defined } \\
\text { as a separate sub-basin }\end{array}$ & $\begin{array}{c}\text { as GI } \\
\text { as a new land use }\end{array}$ & $\begin{array}{lllllll}\checkmark & & \checkmark & \checkmark & \checkmark & \\
\checkmark & \checkmark & \checkmark & \checkmark & \checkmark & & \checkmark\end{array}$ \\
\hline
\end{tabular}

In addition to the spatial data visualization tools, the approach of placing LID as a hydrologic element in the catchment is an important factor. This factor shows how the model can link the flow between individual GIs and catchments in terms of flow routing calculations. In all of the selected models (except models with conceptual design application) two main approaches are considered: the GI is placed within a sub-catchment or the GI is defined as a new sub-catchment. Modelling watershed within a parent watershed reduces the model complexity in terms of reducing the number of modelled watersheds. However, it has the disadvantage of neglecting flow routing across each GI and reduces the flexibility of model in terms of the connection between GIs. On the other hand, considering each GI as a single watershed increases the complexity because of significantly increasing the number of catchments. This second method enhances the flexibility of model in terms of designing a dendritic or loop network to accurately simulate the reality and allows for flow routing within each GI as an independent watershed.

In both PCSWMM and MIKE Urban, modelling GI is possible in both formats, either within a parent watershed as a GI or as an independent new sub-catchment within the main watershed. Win-SLAMM defines GI as an LID practice within the watershed. It divides the watershed into six categories of land use (residential, institutional, commercial, industrial, open and freeways). Then one of fourteen "source areas" is allocated to each land use category (such as turf, roofs, parking, playgrounds, freeways, etc.). Source areas are further categorized conforming to their hydrological nature (for example, whether roofs are flat or pitched and whether they drain directly to the drainage system or drain onto sandy or clayey soils) [71]. As mentioned before, SWAT does not have pre-defined GI, thus, the GI needs to be defined as a watershed. SWAT allows for modelling GI as a new land use within a parent watershed and as a new independent catchment. The other seven tools are either conceptual models, where GIs are considered explicitly within the watershed (GREEN VALUE, L-THIA-LID and WBM) or the GI are not inbuilt in the model and are represented as a new watershed (GIF-Mod, HYDRUS 1D and HEC-HMS).

\subsection{Hydrological Modelling}

\subsubsection{Water Balance Model}

For hydrological modelling of a watershed, a comprehensive water balance model is required to cover all processes occurring in the water cycle and is also used to ensure the model is calibrated correctly. Usually, due to model simplifications, some of these processes are neglected (e.g., snowmelt, evaporation and the water cycle associated with vegetation). However, these processes occur within many GIs (e.g., bioretention cells and green roofs); thus, they are important to consider when modelling LID. Ignoring them may generate inaccurate results and lead to errors in when estimating LID 
performance. Thus, understanding the extent of the simplification in the water balance model of each tool is extremely important.

Table 7 presents a comparison of four parameters: run-on, snowmelt, evaporation and water uptake by plants. These parameters were selected for the comparison because they are commonly neglected in many models. Four out of the eleven selected model (GIF-Mod, HEC-HMS, MIKE Urban, PCSWMM) use several methods for evaporation computations including methods that require light intensity, temperature, wind speed and humidity. A user-defined amount of evaporation is may also be entered into these models (as well as in two other models HYDRUS 1D and WIN-SLAMM). However, RECARGA does not have the capability of modelling evaporation as a time series, and only an average amount of evaporation (regional average evaporation in units of in/day) is used in the computations.

Table 7. Comparing the water balance model parameters of the selected models.

\begin{tabular}{|c|c|c|c|c|c|c|c|c|}
\hline Water Balance Parameters & 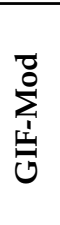 & 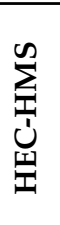 & 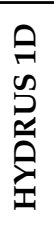 & 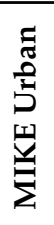 & $\sum_{\substack{\infty \\
\infty}}^{\sum_{\infty}}$ & 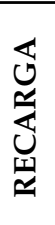 & 量 & 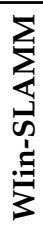 \\
\hline Run-on & $\checkmark$ & $\checkmark$ & & $\checkmark$ & $\checkmark$ & $\checkmark$ & $\checkmark$ & $\checkmark$ \\
\hline Snow melt & & $\checkmark$ & & $\checkmark$ & $\checkmark$ & & $\checkmark$ & \\
\hline Evaporation & $\checkmark$ & $\checkmark$ & $\checkmark$ & $\checkmark$ & $\checkmark$ & $\checkmark$ & $\checkmark$ & $\checkmark$ \\
\hline Water uptake by plants & & & $\checkmark$ & & & & $\checkmark$ & \\
\hline
\end{tabular}

Other than HYDRUS 1D, all the reviewed models allow for receiving run-on from other catchments. In HYDRUS 1D the GI or watershed is not connected to other watersheds, so modelling run-on from an upstream area is not possible. In GIF-Mod catchment blocks are defined to generate the upstream run-on. RECARGA considers the area as two separate parts: the "facility" (e.g., a bioretention cell) and the "tributary" (the upstream drainage area); the latter can generate the run-on towards the facility. While in HEC-HMS, MIKE Urban, PCSWMM, SWAT and Win-SLAMM, the routed flow from upstream areas are considered as run-on and is accounted for in calculations.

Snowmelt modelling is inbuilt in HEC-HMS, MIKE Urban, and PCSWMM, while it cannot be simulated in GIF-Mod, HYDRUS 1D, RECARGA, Win-SLAMM [75]. Processes associated with plants, such as water uptake, interception, through-fall, stem-fall and transpiration, are important processes in LIDs, especially those which have a significant vegetation component. Therefore, the ability of models to model these processes in their water balance model is a major advantage. Six out of the eleven models (GIF-Mod, HEC-HMS, MIK-URBAN, PCSWMM, RECARGA and Win-SLAMM) do not model any of these processes. Only HYDRUS 1D calculates root water uptake [76].

The most thorough water balance model among the reviewed models is the module built within SWAT. It considers several meteorological parameters to calculate the distribution of water in a watershed. SWAT considers solar radiation, wind speed and temperature for computing other parameters such as evaporation and snowmelt. Using these parameters for hydrological modelling, SWAT computes soil water content, evapotranspiration, crop growth, pond and reservoir water balance, groundwater flow and height. These computations are also carried out on occasions when the precipitation is not enough for generating runoff or when the precipitation is zero [37]. This approach is helpful in long-term hydrological modelling of LIDs. In long-term modelling, numerous wet- and dry-period cycles occur, and during the dry period, the change in GI characteristics such as soil moisture content is important and is computed by SWAT.

\subsubsection{Runoff Hydrograph and Peak Generation Method}

Usually, hydrological models generate a hydrograph at the outlet (including an estimate of the peak flow rate) of each watershed according to assigned rainfall data of the watershed. To produce 
this peak flow of runoff, there are various conceptual processes simulated by each model. However, some models are restricted to runoff volume calculation and do not calculate the flow time series (i.e., the hydrograph). Table 8 presents the methods of runoff peak generation of the selected models. In this respect, five models do not calculate the peak flow amount, three of which are conceptual models (GREEN VALUE, L-THIA-LID and WBM). Whereas RECARGA and HYDRUS 1D (which are both single watershed models) do not provide the outflow runoff in time series format and present it as volume and percentage of rainfall. HEC-HMS, PCSWMM, MIKE Urban and Win-SLAMM use the unit hydrograph method and SWAT uses the rational method to generate the peak flow of the outflow hydrograph.

Table 8. Comparing the methods for generating the runoff hydrograph and peak in the selected models.

\begin{tabular}{|c|c|c|c|c|c|c|c|c|c|c|c|}
\hline Runoff Generation Method & $\sum_{0}^{\bar{D}}$ & 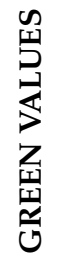 & $\sum_{\substack{1 \\
1}}^{\infty}$ & 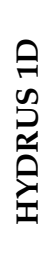 & 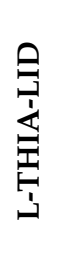 & 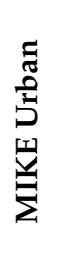 & $\sum_{\substack{\infty \\
\infty}}^{\infty}$ & 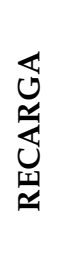 & $\sum_{\infty}^{\frac{1}{3}}$ & $\sum_{3}^{\infty}$ & 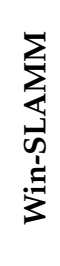 \\
\hline $\begin{array}{l}\text { None } \\
\text { Unit hydrograph (U.H.) methods } \\
\text { Rational method }\end{array}$ & $\checkmark$ & $\checkmark$ & $\checkmark$ & $\checkmark$ & $\checkmark$ & $\checkmark$ & $\checkmark$ & $\checkmark$ & $\checkmark^{1}$ & $\checkmark$ & $\checkmark$ \\
\hline
\end{tabular}

${ }^{1}$ time of concentration lag is used [37].

\subsubsection{Infiltration and Runoff Calculation Method}

Infiltration calculation method is important for LID models because one of the main objectives of implementing LIDs is to increase the amount of infiltration (an important type of loss). Thus, accurately computing the amount of infiltration is an important criterion to select the best-suited model. Methods for computing infiltration consist of common methods such as SCS CN [19] to more complex approaches, such as the Richard's equation, which uses numerical methods. Thus, selecting the degree of the infiltration computation complexity depends on the importance of infiltration in the simulation process. In Table 9 the infiltration calculation method of the selected tools is presented.

Table 9. Comparing the infiltration calculation method of the selected tools.

\begin{tabular}{|c|c|c|c|c|c|c|c|c|c|c|c|}
\hline Infiltration Method & 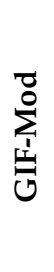 & 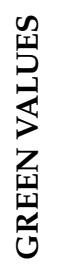 & 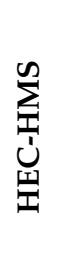 & 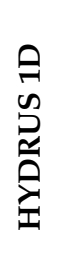 & 署 & 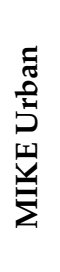 & $\sum_{\substack{\infty \\
\infty}}^{\infty}$ & 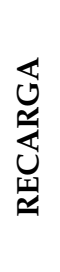 & $\underset{\omega}{\frac{1}{3}}$ & $\sum_{3}^{\infty}$ & 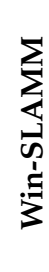 \\
\hline Richard's equation & $\checkmark$ & & & $\checkmark$ & & & & & & & \\
\hline Green-Ampt method & & & $\checkmark$ & & & $\checkmark$ & $\checkmark$ & & $\checkmark$ & & \\
\hline SCS CN & & $\checkmark$ & $\checkmark$ & & $\checkmark$ & $\checkmark$ & $\checkmark$ & $\checkmark$ & $\checkmark$ & & \\
\hline User defined infiltration rate & & & & & & & & & & $\checkmark$ & \\
\hline Experimental infiltration rate & & & & & & & & & & & $\checkmark$ \\
\hline Other Methods & & & $\checkmark$ & & & $\checkmark$ & $\checkmark$ & & & & \\
\hline
\end{tabular}

One of the most common methods to model infiltration is the NRCS SCS Curve Number (CN) method [19]. GREEN VALUES, HEC-HMS, L-THIA-LID, MIKE Urban, PCSWMM, RECARGA and SWAT all have the capacity to model infiltration using this method. Please note that three models, GREEN VALUE, L-THIA-LID and RECARGA, only have the option to use the CN method, whereas the other models have additional inbuilt methods to model infiltration (e.g., Richard's equation, which is 
discussed below). In L-THIA-LID, each GI is considered to be a land use with a specific CN. For example, the values of $\mathrm{CN}$ used to represent hydrologic benefits of bioretention systems are 35, 51, 63 and 70 for Hydrologic Soil Group (HSG) A, B, C and D, respectively [31].

Two of the eleven models (GIF-Mod and HYDRUS 1D) model use Richard's equation to calculate the time series of infiltration. In addition, using Richard's equation allows for modelling multiple layers of soil and modelling the water movement occurring within the soil layers. These abilities present HYDRUS 1D and GIF-Mod as suitable alternatives for designing GI in lab-scale. The other four models (HEC-HMS, MIKE Urban, PCSWMM and SWAT) use the Green-Ampt equation to calculate infiltration. In addition, several other more simplified methods to model infiltration are available in these four models.

Win-SLAMM, unlike the other models, does not use common theoretical (conceptual or physical) formulas for calculating the infiltration depth. The Win-SLAMM infiltration model is based on a set of experimental results. These experiments were carried out on GIs in a laboratory setting with engineered soil media layers. The rate of infiltration for each type of GI was measured using these experiments and assigned within the model. Thus, the Win-SLAMM user needs to select the infiltration rate among the pre-defined data in the model depending on the type of GI and its properties [68]. In contrast, WBM does not compute the infiltration rate using mathematical methods and instead requires a user-defined infiltration rate.

\subsection{Hydraulic Modelling (Flow Routing Method)}

One of the main features associated with hydraulic modelling is the flow routing method between two watersheds. Flow routing methods consist of either kinematic or dynamic wave methods. Yet in some models, flow routing is neglected. Determining the best-suited flow routing method depends on the objective of routing the flow through conduits (i.e., through SCNs). For example, if the objective is to design the real-time control of SCNs and backwater phenomena plays an important role, a dynamic modelling approach is required. Table 10 compares the flow routing method of the selected models.

Table 10. Comparing the flow routing method of the selected models.

\begin{tabular}{|c|c|c|c|c|c|c|c|c|c|c|c|}
\hline Flow Routing Method & 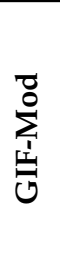 & 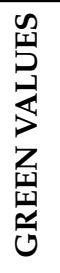 & 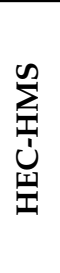 & 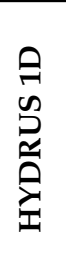 & 罗 & 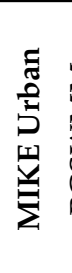 & $\sum_{\substack{\infty \\
\infty}}$ & 志 & 点 & $\sum_{3}^{\infty}$ & 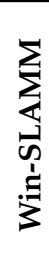 \\
\hline $\begin{array}{c}\text { Steady state (no flow routing) method } \\
\text { Kinematic wave or other hydrologic methods } \\
\text { Dynamic wave } \\
\text { Loop networks modelling }\end{array}$ & $\checkmark$ & $\checkmark$ & $\begin{array}{l}\checkmark \\
\checkmark\end{array}$ & $\checkmark$ & $\checkmark$ & $\begin{array}{l}\checkmark \\
\checkmark \\
\checkmark \\
\checkmark\end{array}$ & $\begin{array}{l}\checkmark \\
\checkmark \\
\checkmark \\
\checkmark\end{array}$ & $\checkmark$ & $\begin{array}{l}\checkmark \\
\checkmark\end{array}$ & $\checkmark$ & $\begin{array}{l}\checkmark \\
\checkmark\end{array}$ \\
\hline
\end{tabular}

Dynamic flow routing is available in PCSWMM and MIKE Urban, which also allow for kinematic wave and static modelling. HEC-HMS, SWAT and Win-SLAMM use the kinematic wave method. It is notable that in Win-SLAMM to attenuate a hydrograph, a control device needs to be defined [68]. Finally, in the other six tools (GIF-Mod, GREEN VALUE, HYDRUS 1D, L-THIA-LID, RECARGA and WBM) flow routing cannot be performed.

It is noticeable that none of the selected models have the ability of designing SCNs. In other words, SCN properties such as conduit slope or section size are required to be assigned by the user. The models are not capable of changing the conduit properties based on a given flow. This makes it difficult to incorporate LIDs and GI within a larger watershed and its SCN. 


\section{Discussion and Gap Analysis}

This review shows that none of the selected model is a comprehensive tool in which all three types of phases (GI design and optimization, conceptual design, preliminary and detailed design/analysis) are allowed. Indeed, most of the tools are well-suited for just one of these applications. On this basis, the selected models were categorized into three separate groups, based on application. In the following sections, comparisons are carried out within each of these groups and a gap analysis is presented.

\subsection{Models with the Application of GI Design and Optimization}

If the main objective of the LID modelling is to explore the effect of GI properties on the GI performance, three out of eleven selected models (GIF-Mod, HYDRUS 1D and RECARGA) are suitable choices. Our review shows that each of these three models are somewhat limited in modelling all types of GI. Therefore, an obvious improvement is to include modelling all additional types of GIs, particularly swales, tree canopy and porous pavements. Regarding swales, none of the existing model can model swales. Modelling the inclined surface and the effect of water movement on the surface while it is infiltrating into the ground is not allowed in these three models. Experimental and 3D modelling of vegetated canals by Przyborowski L. et al. [77] showed that the mean velocity of the flow decreases by minimum $12 \%$ in a planted canal compared to a bare one. Similarly, Loboda et al. [78] showed that aquatic plants (specifically the stem) can influence hydrodynamic processes in vegetated canals (i.e., vegetated swales) and impact the drag and the velocity of flow in these types of canals. Therefore, neglecting these effects brings a notable inaccuracy in LID modelling, particularly with respect to the resulting hydrograph and the time of concentration of flow within these channels. Modelling the inclination or slope of the ground surface requires a 2D approach (with the second dimension being the depth not the ground surface), but these three models are all one dimensional along the soil depth, and thus insufficient. In addition to swales, incorporation of tree canopy or any water cycle associated with plants is not computed in these models. Only, HYDRUS 1D considers the water uptake by plant roots in its modelling.

The main material of the many GIs is soil; however, porous pavements do not fall into this category and are made of a wide range of porous media, such as concrete and asphalt. Since the material is different, the governing equation for modelling the water movement within porous pavement is different from common physical equations for soil. Thus, a new modelling approach is required to accurately and realistically simulate the water processes within porous pavement [79]. This study shows that the three models can only model the physical process of water within the soil material. Adding this ability to these three tools will assist the researchers in better understanding of porous pavement performance and innovating new pavement media and design.

\subsubsection{Water Balance}

None of the three models presents a comprehensive water balance model. Also, all three models (GIF-Mod, HYDRUS 1D and RECARGA) are limited in modelling snowmelt processes; significant impacts of cold climate conditions on GI have been shown in previous studies (e.g., [13,14]), further highlighting the need for improved snowmelt modelling capacity. Water uptake by plants is only modelled in HYDRUS 1D and is not available in the other two models (GIF-Mod and RECARGA). Previous studies have shown that the presence of plants has a major influence on evaporation and loss of soil moisture content $[80,81]$. Therefore, computing these plant-based losses yields a more realistic performance of LIDs such as bioretention cells or rain gardens. Also, receiving run-on from upstream catchment is also not possible in HYDRUS 1D, unlike GIF-Mod and RECARGA, which limits the modelling of the dendritic catchments-an important component of catchment scale modelling of GI systems. 


\subsubsection{RECARGA Limitation}

This review reveals that both GIF-Mod and HYDRUS 1D have more modelling abilities than RECARGA. Some limitations exist in the RECARGA modelling process. For instance, the types of soils are pre-specified, the user cannot assign a customized soil mixture, and the number of soil layers is limited to three layers. In addition, the location of underdrain pipe is fixed between two top soil layers [34] and long-term hydrological simulation is not allowed. Moreover, while the upper and lower boundary conditions at the surface and at lowest soil layer can be defined by the user in GIF-Mod and HYDRUS 1D, this is not possible in RECARGA. Also, GIF-Mod and HYDRUS 1D use Richard's equation to model infiltration, whereas RECARGE uses the SCS CN method. Thus, GIF-Mod and HYDRUS 1D are better suited for more precise bioretention cell designs, while RECARGE is recommended for an estimate.

\subsubsection{Comparing GIF-Mod and HYDRUS 1D}

Despite many similarities between GIF-Mod and HYDRUS 1D with respect to modelling GI, their method of discretization of soil layers is different. HYDRUS 1D uses the conventional mesh generation method and numerical method computations, while GIF-Mod uses soil blocks and analytical solutions. In addition, HYDRUS 1D is a single watershed model, while GIF-Mod connects multiple watersheds via hydraulic links. For these links, GIF-Mod solves the Manning and Darcy-Weisbach equations, which assumes that the flow is uniform and thus, does not require flow routing within the links. Thus, for complex networks and dynamic wave analysis, GIF-Mod may not be a suggested option.

\subsection{Models with the Application of Conceptual Design}

Three out of the eleven models we reviewed (Green Value, WBM and L-THIA-LID) are well-suited for conceptual design and decision-making objectives. This is when detailed information is not available and only an estimation about LIDs performance or cost is required.

There is room for improving the methods of estimating infiltration rate in all three models, since Green Value and L-THIA-LID each use the SCS CN method. The CN procedure is less accurate when runoff is less than 0.5 inches or when the weighted $\mathrm{CN}$ is less than 40 . In addition, the initial abstraction term (Ia), which implicitly includes interception, initial infiltration, surface depression storage, evapotranspiration and other factors. The abstraction term is based on data from agricultural watersheds which may not be appropriate for urban watersheds [82]. In urban areas, the combination of impervious areas with pervious areas can result in a significant initial loss that may not occur in agricultural areas [19]. In addition, $\mathrm{CN}$ has been reported to be the most sensitive variable, having a significant effect on outputs of L-THIA-LID model [83]. Thus, improved infiltration calculate methods is recommended in these models. The present study also shows that none of the three models (Green Value, WBM and L-THIA-LID) cover all types of GI: L-THIA-LID does not consider tree canopy; both GREEN-VALUE and WBM do not include bioretention cells; WBM cannot model green roofs nor cisterns.

\subsection{Models with the Application of Preliminary and Detailed Design/Analysis}

From this review, we found that for preliminary and detailed design modelling of LIDs, five models are available (HEC-HMS, MIKE Urban, PCSWMM, SWAT and Win-SLAMM). However, Win-SLAMM requires detailed parameters and is not suggested for the preliminary design phase, since preliminary design is typically conducted when detailed information is unavailable.

\subsubsection{Integrated Hydrological and Hydraulic Modelling Environment}

Two out of these five models (MIKE Urban and PCSWMM) allow for an integrated hydrological-hydraulic modelling of LIDs incorporated within catchments and SCNs. MIKE Urban 
and PCSWMM carry out a dynamic hydraulic modelling of dendritic and loop networks, which is not possible in any of the other models selected for this review. In addition, these two models offer several types of hydraulic structures, such as gates, reservoirs, orifices, pumps or weirs. These abilities provide an integrated hydrological and hydraulic environment within the MIKE Urban and PCSWMM.

The other three models (Win-SLAMM, HEC-HMS and SWAT) only allow for kinematic wave and static flow routing within conduits and loop network analysis is not possible in these three models. Thus, for modelling complex SCNs, incorporating other hydraulic elements (such as gates, pumps and weirs) these three tools are not suitable. However, the hydrological modelling abilities of these models are adequate.

\subsubsection{Types of GI}

This review shows that none of the five models address all types of LIDs. Tree canopy, bioretention cells and porous pavement are the main limitations in most of the reviewed models. The hydrological process associated with the presence of plants (tree canopy and water uptake by plants) is neglected in PCSWMM, MIKE Urban and Win-SLAMM. Although a vegetation volume is needed to be assigned in PCSWMM and MIKE Urban, it is just the "volume occupied by stems and leaves" in the surface layer and is used to decrease the soil storage volume [36]. Therefore, with these three tools, modelling some types of GI such as tree canopy, bioretention cells and rain gardens, in which plants are a main component, is not suitable. Thus, to model tree canopy, the only remaining alternatives are HEC-HMS and SWAT. However, HEC-HMS does not consider water uptake by plants, while SWAT does. On the other hand, SWAT and HEC-HMS do not allow for modelling bioretention cell and porous pavement. This is because of their limitations in considering different types of media for porous pavement and underdrain pipe for bioretention cells. As a recommended solution, new or updated LID models need to incorporate hydrological processes associated with plants, including interception, stem-fall, water uptake and transpiration [84]. In addition, the ability to model underground perforated pipes (which act as underdrain pipes in GI systems) and ponded surface water with or without GIs (e.g., through the use of berms) are necessary hydraulic elements and are recommended to be included in newer versions of the LID models. Hydrological modelling of materials other than soil or growing media (e.g., concrete or asphalt for permeable pavement systems, or other synthetic materials used as part of GI systems) is also suggested to be included in the selected models so that the runoff generated from these materials can be accurately computed [79].

\subsubsection{Number of Soil Layers}

The customization of GI in terms of changing the number of soil or growing media layers is somewhat limited in most of these five models. Only SWAT can model multiple layers (up to ten layers of soil or growing media). PCSWMM, MIKE Urban and Win-SLAMM consider a maximum of two layers for bioretention cells, while HEC-HMS is limited to one layer for the catchment. The hydrological models typically model the system as a one-dimensional system (with a focus on surface flow), but adding multiple soil layers requires the addition of a second dimension to model the subsurface flow [85]. Modelling subsurface flow has the additional complexity of integrating the flow interactions between the surface and subsurface flow, both in the vadose and saturated zones. To model LID systems more realistically developing an integrated surface-subsurface hydrological model is therefore necessary.

\subsubsection{Temporal Resolution}

A potential improvement was found in terms of temporal resolution of the models. Long-term modelling of LID is important to consider all climatological effects on the LID performance. However, Win-SLAMM and HEC-HMS still have limitations in long-term modelling. The remaining three models (MIKE Urban, PCSWMM and SWAT) support a wide range of temporal resolution. 


\subsubsection{Spatial Consideration of LIDs}

A trend toward adding a GIS-based tool to most of the models is evident, and all models with preliminary or detailed design applications have included some form of GIS-based tool in their model environment. However, there is potential to improve the methods of placing GI in the model. As discussed in Section 3.4, in all selected models, there are two methods of placing GI in the model: "within the catchment" and "as a new catchment". In the former method, the lack of flow routing and the restriction in free linkage of GI are two major limitations. Since one of the substantial effects of implementing GI is peak flow attenuation, neglecting this component will result in less accurate results. Also, to increase the accuracy, adding an ability for free linking the GI within the catchment would be helpful.

The second approach, adding a GI "as a new catchment", does not have the two major limitations mentioned above; however, the complexity associated with the high number of catchments and their links limits the use of this method. Therefore, neither of these two available methods are well-suited for an accurate and time efficient modelling process. Indeed, modelling LID is a multi-scale spatial problem. Since GIs are small-scale elements (e.g., the area of a GI could be as small as $10 \mathrm{~m}^{2}$ ), whereas the scales of the catchments are relatively large compared with the GI (e.g., 100 ha, or greater). Incorporating these two scales, with keeping all GI data, necessitates the use of very high-resolution spatial data. In contrast modelling with low-resolution spatial data will result in loss of a part of GI spatial information (e.g., simplifying the linkage between different GIs). Thus, there is a need for developing a spatial method to optimize and incorporate these two degrees of spatial resolution. The focus of optimization should be on the maximizing the precision of spatial data and minimizing the processing time.

In this review, we compared different components of the water balance model inbuilt in all models. It was found that some main components are missing in most of the models. The water balance model of HEC-HMS, MIKE Urban, PCSWMM and Win-SLAMM do not cover all water cycle processes. None of the four models computes water uptake by plants. In addition, Win-SLAMM does not consider snowmelt in its computations.

Most of the reviewed models in this category consider all common methods for generating the hydrograph and peak flow of catchments. HEC-HMS, MIKE Urban, PCSWMM and Win-SLAMM similarly have no limitation in this respect. In contrast, SWAT only uses the rational method for peak flow generation.

A place for improving the method of infiltration computation exist in all five models. None of these five models uses Richard's equation for calculating the infiltration rate. Most of the models (HEC-HMS, MIKE Urban, PCSWMM and SWAT) use either empirical methods such as SCS CN or analytical equations such as the Green-Ampt method. While the Green-Ampt method is a simplified form of Richard's formula [86], it neglects the temporal effect of soil water content on the hydraulic conductivity, suction head parameters and infiltration rate [86]. Win-SLAMM uses a method entirely different from other models; it considers the results of a series of experiments for calculating the infiltration rate, instead of using physically based equations. This imposes a limitation on the design of the GI because the user can only select their design based on the predefined infiltration rates presented.

\section{Conclusions}

In this review, we selected eleven available models which can be used to model GI and LID. We selected several comparison criteria and performed a comprehensive comparison and evaluation of the models using these criteria. The first criterion was the application of models, which shows the models' ability in modelling watersheds at different scales. Second was the ability of each model to explicitly and implicitly model different types of GI. The next criteria were temporal resolution (minimum and maximum allowed time steps) and spatial data format (including data visualization facilities). The hydrological modelling specifications, including the water balance model, runoff peak 
generation methods, flow routing approaches and infiltration equations were compared. Finally, the flow routing methods used were compared and contrasted.

This review showed that none of the selected model are an integrated environment for all three applications: research, conceptual, preliminary and detailed design applications. Three of the eleven models (GIF-Mod, HYDRUS 1D and RECARGA) are well suited for designing GI for the research phase. Another three models (GREEN VALUE, L-THIA-LID and WBM) only allow for conceptual design of LIDs. Four models (HEC-HMS, MIKE Urban, PCSWMM and SWAT) are recommended for preliminary and detailed design objectives; Win-SLAMM is only recommended for the detailed design phase.

This study revealed that none of the reviewed tools have the ability to model all types of GI. Tree canopy, presence of plants in some GIs (such as bioretention cells, rain gardens), porous pavement, bioretention cells and swales, respectively, are the most commonly neglected GIs in most of the models. In terms of temporal resolution, there is still scope for improvement in some models. Although most of the selected models allow for a wide range of temporal resolutions, in some models (HEC-HMS, RECARGA and Win-SLAMM), long-term modelling is not feasible. In all reviewed models, a trend toward adding spatial data visualization tools is evident. On the other hand, an evaluation and contrasting between the available methods of placing GI in the catchment showed the methods as a hydrologic element is different in the models. Most of the detailed design models can consider GI as a separate independent watershed, which increases the complexity of hydrologic model as well as the model flexibility. Therefore, this may raise the demand for reducing model complexity, while preserving the flexibility of GI connections.

Other than SWAT, all other reviewed models require an improvement in their water balance model. Most of the models neglect plant effects on the water balance, such as water uptake by plants. In addition, snowmelt is not considered in four out of eleven models (GIF-Mod, HYDRUS 1D, RECARGA and Win-SLAMM), which is especially important for LID applications in cold climate regions. In terms of receiving water from upstream catchments, ten of the eleven reviewed models considered this feature. However, HYDRUS 1D does not allow for accepting run-on from another catchment.

Looking at the methods of generating the peak of the runoff hydrograph, the review showed that four out of five preliminary and detailed design models (HEC-HMS, MIKE Urban, PCSWMM, Win-SLAMM) use the unit hydrograph-based method. However, SWAT uses the rational method (which does not provide a time series, only an estimate of the peak flow); thus, this leaves a place for improvement of SWAT in this respect.

From this review, we found that in most of the models, the method used for computing infiltration needs to be improved. The most comprehensive method (Richard's formula) is only used by two models (GIF-Mod and HYDRUS 1D). Four models (HEC-HMS, MIKE Urban, PCSWMM and SWAT) use a wide range of other common methods (e.g., Green-Ampt, SCS CN). Other models only use one method, such as SCS CN (GREEN VALUE, L-THIA-LID and RECARGA), user defined rate (WBM) or experimental values (Win-SLAMM).

An improvement in the hydraulic modelling, particularly, flow routing method in most of the models (except MIKE Urban and PCSWMM) is recommended. Dynamic flow routing and loop connections design are missing in HEC-HMS, Win-SLAMM and SWAT, which are the models suitable for modelling large-scale catchments. Therefore, if the concern of the modelling is to consider backwater effect or loop junctions in the SCN, only two alternative remains (MIKE Urban and PCSWMM).

Although an improving trend of LID modelling is evident in new versions of the models, extensive improvements are still required to accurately and realistically simulate the performance of LIDs. These are including improvement of modelling all range of GI and temporal resolution; enhancing the inbuilt water balance of model, improving the methods for generating the catchment hydrograph, improving the infiltration calculation method; optimizing the spatial modelling approaches and ultimately enhancing the hydraulic modelling methods. 
Author Contributions: Conceptualization, S.K., U.T.K. and A.J.; Formal analysis, S.K.; Writing-original draft preparation, S.K.; Writing—review and editing, U.T.K. and A.J.; supervision, U.T.K. and A.J.

Funding: This research was funded by the Natural Sciences and Engineering Research Council of Canada and York University.

Acknowledgments: The authors would like to thank the CHI Inc. for granting the student version of the PCSWMM model. We would also like to thank the three reviewers for their feedback, which has helped improve the quality of the manuscript.

Conflicts of Interest: The authors declare no conflict of interest.

\section{Abbreviations}

$\begin{array}{ll}\text { CN } & \text { Curve Number } \\ \text { GI } & \text { Green Infrastructure } \\ \text { GIF-Mod } & \text { Green Infrastructure Flexible Model } \\ \text { GIS } & \text { Geographical Information System } \\ \text { GUI } & \text { Graphical User Interface } \\ \text { HEC-HMS } & \text { Hydrologic Engineering Centre-Hydrologic Modelling System } \\ \text { LID } & \text { Low Impact Development } \\ \text { L-THIA-LID } & \text { Long-Term Hydrologic Impact Assessment Model } \\ \text { MOUSE } & \text { MOdel for Urban Sewers } \\ \text { SCN } & \text { Stormwater Collection Network } \\ \text { SWAT } & \text { Soil and Water Assessment Tool } \\ \text { SWMM } & \text { Stormwater Management Model } \\ \text { WBM } & \text { Water Balance Model } \\ \text { Win-SLAMM } & \text { Win-Source Loading and Management Model }\end{array}$

\section{Appendix A}

1. Flood Map Modelling (FMM) [87].

2. Green Infrastructure Flexible Model (GIF-Mod).

3. Green Values National Stormwater Management Calculator [28].

4. Gridded Surface Subsurface Hydrologic Analysis Model (GSSHA) [88].

5. Hydrologic Engineering Centre- Hydrologic Modelling System (HEC-HMS) [47].

6. HYDRUS [76].

7. Long-Term Hydrologic Impact Assessment Model (L-THIA-LID) [55].

8. MIKE Urban/ MOdel for Urban Sewers (MOUSE) [56].

9. Model for Urban Stormwater Improvement Conceptualization (MUSIC) [89].

10. Probabilistic Urban Rainwater and wastewater Reuse Simulator (PURRS) [90].

11. RECARGA [34].

12. RUNoff QUALity (RUNQUAL) [91,92].

13. SewerGems [93].

14. Soil and Water Assessment Tool (SWAT) [38].

15. StormCad [94].

16. Storm Water Management Model (PCSWMM) [35].

17. Structural BMP Prioritization and Analysis Tool (SBPAT) [95].

18. Temporal evolution modelling of hydraulic and water quality performance of permeable pavements (TMPP) [78].

19. Urban Catchment Model (P8-UCM) [96].

20. Urban Volume and Quality (UVQ) [97].

21. Water Balance Model (WBM) [66].

22. Water Environment Research Foundation Whole Life Cost Models (WERF WLCM) [98,99].

23. Watershed Modelling System (WMS) [100,101].

24. Win-Source Loading and Management Model (Win-SLAMM) [42].

\section{References}

1. Dietz, M.E. Low impact development practices: A review of current research and recommendations for future directions. Water Air Soil Pollut. 2007, 186, 351-363. [CrossRef] 
2. Mouritz, M. No Sustainable Urban Water Systems; Policy \& Professional Praxis; Murdoch University: Perth, Australia, 1992.

3. Whelans, C.; Maunsell, H.; Thompson, P. Planning and Management Guidelines for Water Sensitive Urban (Residential) Design; Department of Planning and Urban Development of Western Australia: Perth, Australia, 1994.

4. Coffman, L.S.; Goo, R.; Frederick, R. Low-Impact Development an Innovative Alternative Approach to Stormwater Management. In Proceedings of the 29th Annual Water Resources Planning and Management Conference, Tempe, AZ, USA, 6-9 June 1999; pp. 1-10.

5. McCuen, R.H. Smart Growth: Hydrologic Perspective. J. Prof. Issues Eng. Educ. Pract. 2003, 129, $151-154$. [CrossRef]

6. Heal, K.; Mclean, N.; D'arcy, B. SUDS and Sustainability. In Proceedings of the 26th Meeting of the Standing Conference on Stormwater Source Control, Copenhagen, Denmark, 21-26 August 2004; pp. 1-9.

7. Fletcher, T.D.; Shuster, W.; Hunt, W.F.; Ashley, R.; Butler, D.; Arthur, S.; Trowsdale, S.; Barraud, S.; Semadeni-Davies, A.; Bertrand-Krajewski, J.L.; et al. SUDS, LID, BMPs, WSUD and more-The evolution and application of terminology surrounding urban drainage. Urban Water J. 2015, 12, 525-542. [CrossRef]

8. Coffman, L. Low Impact Development: Smart Technology for Clean Water. In Proceedings of the 9th International Conference on Urban Drainage, Portland, OR, USA, 9-13 September 2002; pp. 1-11.

9. Friedlich, B.; Bergstrom, J. Engineering Concepts for Bioretention Facilities: From Rain Gardens to Basins. Proceedings of the New Jersey Chapter of the American Society of Landscape Architects 2011 Annual Meeting E Expo, 2011. Available online: https://www.yumpu.com/en/document/view/30381868/engineering-conceptsfor-bioretention-facilities-rutgers- (accessed on 27 October 2018).

10. American Rivers, Tetra Tech. Low Impact Development Manual for the Lower Maumee and Ottawa River Watersheds; American Rivers, Tetra Tech.: Washington, DC, USA, 2010; Available online: http:// mvparkdistrict.org/pdf/nwo_lid_manual.pdf (accessed on 27 October 2018).

11. County, M.P.G.; Coffman, L. Low-Impact Development Design Strategies an Integrated Design Approach Low-Impact Development: An Integrated Design Approach; Department of Environmental Resources, Programs and Planning Division: Prince George's County, MD, USA, 1999.

12. Cheng, M.-S.; Coffman, L.S.; Clar, M.L. Low-impact development hydrologic analysis. In Proceedings of the Specialty Symposium on Urban Drainage Modeling at the World Water and Environmental Resources Congress, Orlando, FL, USA, 20-24 May 2001; pp. 659-681. [CrossRef]

13. Khan, U.T.; Valeo, C.; Chu, A.; van Duin, B. Bioretention cell efficacy in cold climates: Part 2-Water quality performance. Can. J. Civ. Eng. 2012, 39, 1222-1233. [CrossRef]

14. Khan, U.T.; Valeo, C.; Chu, A.; He, J. A Data Driven Approach to Bioretention Cell Performance: Prediction and Design. Water 2013, 5, 13-28. [CrossRef]

15. Elliott, A.H.; Trowsdale, S.A. A review of models for low impact urban stormwater drainage. Environ. Model. Softw. 2006, 22, 394-405. [CrossRef]

16. Ahiablame, L.M.; Engel, B.A.; Chaubey, I. Effectiveness of low impact development practices: Literature review and suggestions for future research. Water Air Soil Pollut. 2012, 223, 4253-4273. [CrossRef]

17. The City of Edmonton. Low Impact Development Best Management Practices Design Guide Edition 1.1, no. December 2014; The City of Edmonton: Edmonton, AB, Canada, 2014; pp. 1-269. Available online: https: / / www.edmonton.ca/city_government/documents/PDF/LIDGuide.pdf (accessed on 27 October 2018).

18. Carson, T.; Keeley, M.; Marasco, D.E.; McGillis, W.; Culligan, P. Assessing methods for predicting green roof rainfall capture: A comparison between full-scale observations and four hydrologic models. Urban Water J. 2017, 14, 589-603. [CrossRef]

19. USDA Natural Resource Conservation Service. Urban Hydrology for Small Watersheds TR-55; USDA Natural Resource Conservation Service: Washington, DC, USA, 1986.

20. Carson, T.B.; Marasco, D.E.; Culligan, P.J.; McGillis, W.R. Hydrological performance of extensive green roofs in New York City: Observations and multi-year modeling of three full-scale systems. Environ. Res. Lett. 2013, 8, 024036. [CrossRef]

21. Schroeder, P.R.; Lloyd, C.M.; Zappi, P.A.; Aziz, N.M.; Landreth, R.E. The Hydrologic Evaluation of Landfill Performance (HELP) Model, User Guide for Version 3; Risk Reduction Engineering Laboratory, Office of Research and Development, US Environmental Protection Agency: Washington, DC, USA, 2017. 
22. Niazi, M.; Nietch, C.; Maghrebi, M.; Jackson, N.; Bennett, B.R.; Tryby, M.; Massoudieh, A. Stormwater management model: Performance review and gap analysis. J. Sustain. Water Built Environ. 2017, 3, 04017002. [CrossRef]

23. Obropta, C.C.; Kardos, J.S. Review of urban stormwater quality models: Deterministic, stochastic, and hybrid approaches. J. Am. Water Resour. Assoc. 2007, 43, 1508-1523. [CrossRef]

24. Jayasooriya, V.M.; $\mathrm{Ng}$, A.W.M. Tools for modeling of stormwater management and economics of green infrastructure practices: A review. Water Air Soil Pollut. 2014, 225, 2055. [CrossRef]

25. Shrivastava, P. Urban Water Hydrological Modelling. Int. J. Latest Trends Eng. Technol. 2016, 7, 489-493.

26. Massoudieh, A.; Maghrebi, M.; Kamrani, B.; Nietch, C.; Tryby, M.; Aflaki, S.; Panguluri, S. A flexible modeling framework for hydraulic and water quality performance assessment of stormwater green infrastructure. Environ. Model. Softw. 2017, 92, 57-73. [CrossRef]

27. GIF-Mod. Massoudieh, Arash Maghrebi, Mahdi Kamrani, Babak Nietch, Christopher ryby, Michael Aflaki, Sassan Panguluri, Srinivas, 2017. Available online: http:/ /gifmod.com/download-gifmod-installation-file/ (accessed on 27 October 2018).

28. U.S. Environmental Protection Agency (EPA). Green Value National Stormwater Management Calculator Tool. 2017. Available online: http://greenvalues.cnt.org/national/calculator.php (accessed on 27 October 2018).

29. Severson, L.; Atchison, D. RECARGA User 's Manual; University of Wisconsin: Madison, WI, USA, 2004.

30. BCIGP. Water Balance Tools for British Columbia Inter-Governmental Partnership. 2017. Available online: http:/ / waterbalance.ca/tools-resources / (accessed on 27 October 2018).

31. BCIGP. Water Balance Model for British Columbia Inter-Governmental Partnership. 2017. Available online: http:/ / waterbalance.ca/tool/water-balance-desktop/ (accessed on 27 October 2018).

32. Engel, B.; Harbor, J. The L-THIA LID Model Description (Purdue University). 2017. Available online: https: / / engineering.purdue.edu/mapserve/LTHIA7/lthianew/lidIntro.php (accessed on 27 October 2018).

33. U.S. Army Corps of Engineers. HEC-HMS Features; U.S. Army Corps of Engineers: Washington, DC, USA, 2017; pp. 1-4.

34. Pitt, R. WinSLAMM and Low Impact Development. In Proceedings of the Low Impact Development Conference, College Park, MD, USA, 21-23 September 2004; pp. 1-14.

35. P. \& Associates. Win-SLAMM Sources. 2017. Available online: http://unix.eng.ua.edu/ rpitt/ SLAMMDETPOND/WorkshopPresentations.html (accessed on 27 October 2018).

36. PC Progress. HYDRUS. 2017. Available online: https://www.pc-progress.com/en/Default.aspx?H1Ddescription\#k1 (accessed on 27 October 2018).

37. Neitsch, S.; Arnold, J.; Kiniry, J.; Williams, J. Soil \& Water Assessment Tool (SWAT) Theoretical Documentation Version 2009; Texas Water Resources Institute: College Station, TX, USA, 2009.

38. Texas A \& M University and USDA Agricultural Research Service. SWAT Website. 2018. Available online: http:/ / swat.tamu.edu/software/swat-executables/ (accessed on 27 October 2018).

39. DHI Inc. Hydrologic Modeling Inventory Model Description Form; DHI Inc.: New York, NY, USA, 1999; p. 4.

40. DHI Inc. Mike Urban Release Note; DHI Inc.: New York, NY, USA, 2017; Available online: http:/ / releasenotes. dhigroup.com/2016/MIKEURBANrelinf.htm (accessed on 27 October 2018).

41. James, W.; Rossman, L.A.; James, W.R. User's Guide to SWMM5, 13th ed.; CHI: Guelph, ON, Canada, 2010.

42. Computational Hydraulics International (CHI). PCSWMM. 2017. Available online: https://www.pcswmm. com/ (accessed on 27 October 2018).

43. Massoudieh, A. User's Manual for Green Infrastructure Flexible Model (GIFMod); GIFMod: Washington, DC, USA, 2016.

44. Haris, H.; Chow, M.F.; Usman, F.; Sidek, L.M.; Roseli, Z.A.; Norlida, M.D. Urban Stormwater Management Model and Tools for Designing Stormwater Management of Green Infrastructure Practices; IOP: London, UK, 2016; p. 32 .

45. Schifman, L.A.; Tryby, M.E.; Berner, J.; Shuster, W.D. Managing Uncertainty in Runoff Estimation with the U.S. Environmental Protection Agency National Stormwater Calculator. J. Am. Water Resour. Assoc. 2018, 54, 148-159. [CrossRef]

46. U.S. Environmental Protection Agency (EPA). National Green Values Calculator Methodology; EPA: Washington, DC, USA, 2009. 
47. U.S. Army Corps of Engineers (USACE). Hydrologic Modeling System (HEC-HMS) Technical Reference Manual; USACE: Washington, DC, USA, 2000.

48. Khaniya, B.; Wanniarachchi, S.; Rathnayake, U. Importance of Hydrologic Simulation for Lids and BMPs Design Using HEC-HMS: A Case Demonstration. Int. J. Hydrol. Import. 2017, 1, 1-10.

49. Zope, P.E.; Eldho, T.I.; Jothiprakash, V. Impacts of land use-land cover change and urbanization on flooding: A case study of Oshiwara River Basin in Mumbai, India. Catena 2016, 145, 142-154. [CrossRef]

50. US Army Corps of Engineers (USACE). Hydrologic Modeling System (HEC_HMS) User 's Manual; USACE: Washington, DC, USA, 2016.

51. Li, J.; Zhao, R.; Li, Y.; Chen, L. Modeling the effects of parameter optimization on three bioretention tanks using the HYDRUS-1D model. J. Environ. Manag. 2018, 217, 38-46. [CrossRef] [PubMed]

52. Turco, M.; Kodešová, R.; Brunetti, G.; Nikodem, A.; Fér, M.; Piro, P. Unsaturated hydraulic behaviour of a permeable pavement: Laboratory investigation and numerical analysis by using the HYDRUS-2D model. J. Hydrol. 2017, 554, 780-791. [CrossRef]

53. Šimůnek, J.; van Genuchten, M.T.; Šejna, M. Development and Applications of the HYDRUS and STANMOD Software Packages and Related Codes. Vadose Zone J. 2008, 7, 587. [CrossRef]

54. Liu, Y.; Cibin, R.; Bralts, V.F.; Chaubey, I.; Bowling, L.C.; Engel, B.A. Optimal selection and placement of BMPs and LID practices with a rainfall-runoff model. Environ. Model. Softw. 2016, 80, 281-296. [CrossRef]

55. U.S. Army Corps of Engineers. L-THIA LID Tutorials; U.S. Army Corps of Engineers: Washington, DC, USA, 2017.

56. DHI Inc. MIKE URBAN Tutorials; DHI Inc.: New York, NY, USA, 2017; p. 232.

57. DHI Inc. Modelling of Stormwater Drainage Networks and Sewer Collection Systems Using MIKE URBAN; DHI Inc.: New York, NY, USA, 2017.

58. Muthanna, T.M.; Viklander, M.; Thorolfsson, S.T. Bioretention sizing methods applied to cold climates with snow storage conditions. Water Sci. Technol. 2007, 10, 73-81. [CrossRef] [PubMed]

59. Boancă, P.; Dumitraș, A.; Luca, L.; Bors-Oprișa, S.; Laczi, E. Analysing Bioretention Hydraulics and Runoff Retention through Numerical Modelling Using RECARGA: A Case Study in a Romanian Urban Area. Polish J. Environ. Stud. 2018, 27, 1965-1973. [CrossRef]

60. Green, H.W.; Ampt, G. Studies on Soil Phsyics. J. Agric. Sci. 1911, 4, 1-24. [CrossRef]

61. van Genuchten, M.T. A closed-form equation for predicting the hydraulic conductivity of unsaturated soils. Soil Sci. Soc. Am. J. 1980, 44, 892-898. [CrossRef]

62. Rees, P.; Schoen, J. PCSWMM Evaluation; Water Resources Research Centre, University of Massachusetts: Boston, MA, USA, 2009.

63. Ahiablame, L.; Shakya, R. Modeling flood reduction effects of low impact development at a watershed scale. J. Environ. Manag. 2016, 171, 81-91. [CrossRef] [PubMed]

64. Zhang, K.; Chui, T.F.M. A comprehensive review of spatial allocation of LID-BMP-GI practices: Strategies and optimization tools. Sci. Total Environ. 2018, 621, 915-929. [CrossRef] [PubMed]

65. Arnold, J.G.; Kiniry, J.R.; Srinivasan, R.; Williams, J.R.; Haney, E.B.; Neitsch, S.L. Soil E Water Assessment Tool (SWAT): Input/Output Documentation; Texas Water Resources Institute: College Station, TX, USA, 2012.

66. Partnership for Water Sustainability of British Columbia. Water Balance Model (WBM). 2018. Available online: http:/ / waterbalance.ca/wbm/ (accessed on 27 October 2018).

67. Pitt, R.; Voorhees, J. SLAMM, the Source Loading and Management Model. In Wet-Weather Flow Urban Watershed Technology Management; CRC Press: Boca Raton, FL, USA, 2002; pp. 103-139.

68. PV \& Associates. WinSLAMM Model Algorithms; PV \& Associates: Tuscaloosa, AL, USA, 2015.

69. Pitt, R. Small storm hydrology and why it is important for the design of stormwater control practices. Adv. Model. Manag. 1999, 7, 1-31. [CrossRef]

70. Pit, R.; Lantrip, J.; Harrison, R.; Henry, C.L.; Xue, D. Infiltration Through Disturbed Urban Soils and Compost-Amended Soil Effects on Runoff Quality and Quantity Research Report. U.S. Environmental Protection Agency, Water Supply and Water Resources Division; National Risk Management Research Laboratory: Cincinnati, OH, USA, 1999.

71. Rodman, D.; Hart, D.; Lemke, B. The Use of GIS to Support Operation of the Source Loading and Management Model (SLAMM) for Analysis of Urban Non-Point Source Pollution; UW-Madison Land Information \& Computer Graphics Facility: Madison, WI, USA, 2017; pp. 1-27. 
72. Gülbaz, S.; Kazezyılmaz-Alhan, C.M. Hydrological Model of LID with Rainfall-Watershed-Bioretention System. Water Resour. Manag. 2017, 31, 1931-1946. [CrossRef]

73. Mein, R.G.; Larson, C.L. Modeling infiltration during a steady rain. Water Resour. Res. 1973, 9, $384-394$. [CrossRef]

74. PV \& Associates. Arc SLAMM Plus Overview by UNI GeoTREE Center; 2013. Available online: http:// rpitt.eng.ua.edu/SLAMMDETPOND/WorkshopPresentations/8b_ArcSLAMM_Grayscale.pdf (accessed on 27 October 2018).

75. Pitt, R. WIN-SLAMM Website. 2017. Available online: http://unix.eng.ua.edu/ rpitt/SLAMMDETPOND/ WinSlamm/Ch1/Ch1.html (accessed on 27 October 2018).

76. PC-Progress. HYDRUS Software Applications to Subsurface Flow and Contaminant Transport Problems. In Proceedings of the 5th International Conference HYDRUS Software Applications to Subsurface Flow and Contaminant Transport Problems, Prague, Czech, 30-31 March 2017; p. 50.

77. Przyborowski, Ł.; Łoboda, A.; Bialik, R. Experimental Investigations of Interactions between Sand Wave Movements, Flow Structure, and Individual Aquatic Plants in Natural Rivers: A Case Study of Potamogeton Pectinatus L. Water 2018, 10, 1166. [CrossRef]

78. Łoboda, A.M.; Karpiński, M.; Bialik, R.J. On the Relationship between Aquatic Plant Stem Characteristics and Drag Force: Is a Modeling Application Possible? Water 2018, 10, 540. [CrossRef]

79. Huang, J.; He, J.; Valeo, C.; Chu, A. Temporal evolution modeling of hydraulic and water quality performance of permeable pavements. J. Hydrol. 2016, 533, 15-27. [CrossRef]

80. Denich, C.; Bradford, A. Estimation of Evapotranspiration from Bioretention Areas Using Weighing Lysimeters. J. Hydrol. Eng. 2010, 15, 522-530. [CrossRef]

81. Berghage, R.; Jarrett, A.; Beattie, D.; Kelley, K.; Husain, S.; Rezai, F.; Long, B.; Negassi, A.; Cameron, R.; Hunt, W. Quantifying Evaporation and Transpirational Water Losses from Green Roofs and Green Roof Media Capacity for Neutralizing Acid Rain, National Decentralized Water Resources Capacity Development Project Research Project. 2007. Available online: http:/ / www.decentralizedwater.org/documents / 04-dec10sg/04-dec-10sg.pdf (accessed on 27 October 2018).

82. Al-Rawas, G.A.; Valeo, C.; Khan, U.T.; Al-Hafeedh, O.H. Effects of urban form on wadi flow frequency analysis in the Wadi Aday watershed in Muscat, Oman. Urban Water J. 2015, 12, 263-274. [CrossRef]

83. Liu, Y.; Chaubey, I.; Bowling, L.C.; Bralts, V.F.; Engel, B.A. Sensitivity and Uncertainty Analysis of the L-THIA-LID 2.1 Model. Water Resour. Manag. 2016, 30, 4927-4949. [CrossRef]

84. Bonan, G. Ecological Climatology; Cambridge University Press: Cambridge, UK, 2016.

85. Davison, J.H.; Hwang, H.T.; Sudicky, E.A.; Mallia, D.V.; Lin, J.C. Full Coupling Between the Atmosphere, Surface, and Subsurface for Integrated Hydrologic Simulation. J. Adv. Model. Earth Syst. 2018, 10, 43-53. [CrossRef]

86. Chow, V.T.; Maidment, D.R.; Mays, L.W. Applied Hydrology; McGrawHill: New York, NY, USA, 1988.

87. Yu, D.; Yin, J.; Liu, M. Validating city-scale surface water flood modelling using crowd-sourced data. Environ. Res. Lett. 2016, 11, 1748-9326. [CrossRef]

88. US Army Corps of Engineers (USACE). Gridded Surface Subsurface Hydrologic Analysis (GSSHA). 2017. Available online: http://www.gsshawiki.com/Gridded_Surface_Subsurface_Hydrologic_Analysis (accessed on 27 October 2018).

89. eWater. Model for Urban Stormwater Improvement Conceptualization (MUSIC). 2017. Available online: http:/ / www.ewater.org.au/products/music/ (accessed on 27 October 2018).

90. Lucas, S.; Coombes, P.; Geary, P.; Dunstan, H. Rainwater harvesting and wastewater reuse in peri-urban areas. In Proceedings of the 13th International Rainwater Catchment Systems Conference and 5th Water Sensitive Urban Design Conference, Sydney, Australia, 21-23 August 2007.

91. New York State Water Resources Institute. RUNQUAL. 2018. Available online: https://wri.cals.cornell.edu (accessed on 27 October 2018).

92. Haith, D.A. RUNQUAL Runoff Quality from Development Sites User's Manual Department of Agricultural \& Biological Engineering, Cornell University. 1999. Available online: http://www.mapshed.psu.edu/ Downloads/RUNQUALManual.pdf (accessed on 27 October 2018).

93. Bentley. 2018. Available online: https://www.bentley.com (accessed on 27 October 2018). 
94. Bentley. Storm Sewer Analysis and Design Software, StormCAD V8. 2016. Available online: https:// www.bentley.com/en/products/product-line/hydraulics-and-hydrology-software/stormcad (accessed on 27 October 2018).

95. Geosytntec Consultants. A User's Guide for the Structural BMP Prioritization and Analysis Tool (SBPAT v1.0); Geosyntec: Los Angeles, CA, USA, 2008.

96. Walker, W.W. P8 Urban Catchment Model-Program Documentation Version 1.1. vol. Prepared f, no. October 1990. Available online: http:/ / www.wwwalker.net/p8/ (accessed on 27 October 2018).

97. Mitchell, V.G.; Diaper, C. UVQ: A tool for assessing the water and contaminant balance impacts of urban development scenarios. Water Sci. Technol. 2005, 52, 91-98. [CrossRef] [PubMed]

98. Houdeshel, C.D.; Pomeroy, C.A.; Hair, L.; Goo, R. Cost estimating tools for low-impact development best management practices. In Proceedings of the World Environmental and Water Resources Congress, Kansas City, MO, USA, 17-21 May 2009; Volume 342, pp. 991-1003.

99. Hair, L.; Moeller, J. Cost-Estimating Tools for Low-Impact Development Best Management Practices: Challenges, Limitations, and Implications. J. Irrig. Drain. Eng. 2011, 137, 183-189.

100. Aquaveo. WMS: Introduction to WMS. 2017. Available online: http://www.xmswiki.com/wiki/WMS: Introduction_to_WMS (accessed on 27 October 2018).

101. Brigham Young University. Watershed Modeling System WMS v7.1 TUTORIALS; Brigham Young University: Provo, UT, USA, 2004; p. 311.

(C) 2018 by the authors. Licensee MDPI, Basel, Switzerland. This article is an open access article distributed under the terms and conditions of the Creative Commons Attribution (CC BY) license (http://creativecommons.org/licenses/by/4.0/). 